\title{
A SKETCH OF ONGOTA A DYING LANGUAGE OF SOUTHWEST ETHIOPIA*
}

\author{
Graziano Savà \\ Leiden University, The Netherlands \\ Mauro Tosco \\ Istituto Universitario Orientale, Naples, Italy
}

The article provides a grammatical sketch of Ongota, a language on the brink of extinction (actively used by eight out of an ethnic group of nearly one hundred) spoken in the South Omo Zone of Southwestern Ethiopia. The language has now been largely superseded by Ts'amakko, a neighboring East Cushitic language, and code-switching in Ts'amakko occurs extensively in the data. A peculiar characteristic of Ongota is that tense distinctions on the verb are marked only tonally. Ongota's genetic affiliation is uncertain, but most probably Afroasiatic, either Cushitic or Omotic; on the other hand, it must be noted that certain features of the language (such as the almost complete absence of nominal morphology and of inflectional verbal morphology) point to an origin from a creolized pidgin.

\footnotetext{
${ }^{*}$ We are grateful to the Italian National Research Center (C.N.R.) for funding the research upon which this paper is based, and to the Institute of Ethiopian Studies at Addis Ababa University for granting us the permission to carry on our fieldwork in the area. Previous data on various points of Ongota grammar has been presented jointly by the authors at the "XIVth International Conference of Ethiopian Studies" (Addis Ababa, November 6-11, 2000) and, by Graziano Savà, at the Symposium "Ethiopian Morphosyntax in an Areal Perspective" (Leiden, February 4-5, 2001). We thank all those who, with their comments and suggestions, greatly improved our understanding of Ongota. Special thanks are due to Aklilu Yilma (Addis Ababa University). Obviously, any error and omission is entirely our responsibility.
} 


\section{CONTENTS}

1. Introduction

2. Phonology

2.1. Segments

2.2. Allophonic variation

2.2.1. Voicing opposition

2.2.2. Labial alternation

2.2.3. Fricativization

2.2.4. Glottalization

2.3. Phonological processes

2.3.1. Final Height Neutralization

2.3.2. Final Vowel Dropping

2.3.3. Glottal Onset Insertion

2.3.4. Final Glottal Deletion

2.3.5. Final Devoicing

2.3.6. Final Non-release

2.3.7. Uvular Spirantization

2.4. Assimilations

2.4.1. Assimilation to a dental

2.4.2. Nasal Assimilation

2.4.3. Sibilant harmony

2.5. Syllables

2.6. Clusters and epenthesis

2.7. Length

2.8. Suprasegmentals

2.9. Treatment of Ts'amakko loans

2.10. Words, affixes and clitics

3. Morphology

3.1. Word-classes

3.2. Nouns

3.2.1. Number

3.2.1.1. Singulative

3.2.2.2. Plural and Collective

3.2.2. Gender 
3.3. Pronouns

3.3.1. Emphatic Pronouns

3.3.2. Subject Clitics

3.3.3. Object Pronouns

3.3.4. Indirect Pronouns

3.3.5. Possessives

3.3.6. Postpositional series and other pronominals used with adpositional elements

3.4. Deictics and Determiners

3.5. Adpositions

3.5.1. Spatial relations

3.6. Adjectives

3.6.1. Basic adjectives

3.6.2. Derived adjectives

3.6.3. Verbs with adjectival meaning

3.6.4. Colors

3.6.5. Adjectival phrases

3.6.6. Comparatives and superlatives

3.7. Numerals

3.7.1. Cardinals

3.7.2. Numeral phrases

3.8. Adverbs

3.9. Verbs

3.9.1 Basic stems

3.9.1.1. Plural stems

3.9.2. Derived stems

3.9.2.1. Causative

3.9.2.2. Middle

3.9.2.3. Intransitive

3.9.2.4. Frozen derivational extensions?

3.9.3. Tense

3.9.4. Aspect

3.9.5. Negative paradigms

3.9.6. Imperative

3.9.6.1. Irregular Imperatives

3.9.6.2. Negative Imperative

3.9.7. Jussive

3.9.8. Infinitive

3.9.9. 'to have' 
4. Syntax

4.1. Noun Phrases

4.2. Genitival phrases

4.3. Sentences

4.3.1. Subjects

4.3.2. Objects

4.3.3. Passive (Impersonal construction)

4.3.4. Reciprocal and Reflexive

4.4. Questions

4.4.1. Content questions

4.4.2. Polar questions

4.4.3. Greetings

4.5. Direct speech

4.6. Nominal sentences

4.7. Relative clauses

4.8. Object and subject sentences

4.9. Sentence embedding

4.10. Coordination

4.11. Focus

5. Ongota lexicon

6. English-Ongota index

References

Map 


\section{Introduction ${ }^{1}$}

The extreme southwestern corner of Ethiopia is well-known as an ethnic and linguistic mosaic. What was formerly the western part of Gemu-Gofa and is now the Southern Omo Zone (Amharic: yä-däbub omo zon) of the "Southern Peoples, Nations and Nationalities Region" comprises peoples speaking Cushitic and Omotic languages of the Afroasiatic family, as well as Nilotic and Surmic languages of the Eastern Sudanic branch of Nilo-Saharan. But there is at least another enigmatic people, mostly known in the area as Birale, but whose ethnic selfname is rather Ongota ( Songota [fongóta]). One would search in vain for either the Birale or the Ongota in the Ethiopian census (Federal Democratic Republic of Ethiopia 1998). The state of our knowledge about this people and their language (iifa longota 'language ["mouth"] of the Ongota') is well summarized in Ethnologue's entry, quoted here below:

Birale (Ongota, Birelle, Ifa'Ongota, "Shanqilla") [BXE] 20 speakers out of an ethnic group of 70 (SIL 1990). One village on the west bank of the Weyt'o River, southeast Omo Region. Afroasiatic, Unclassified. All the speakers are old. The others conduct their affairs in Tsamai. $18 \%$ lexical similarity with Tsamai, but from borrowing. Typology: SOV; postpositions; genitives follow noun heads; suffixes indicate noun case; verb affixes mark subject person, number, and gender; passive; causative. Agriculturalists, hunters. Nearly extinct. [Grimes 1996: 260]

The entry itself represents a decisive improvement over previous reports, such as, for example, Ethnologue's 11th edition, where the language was said to be spoken '[O]n Lake Weyto, north of the Cushitic-speaking Tsamay' [Grimes 1991: 218]. At least at the present time, no such thing as a (permanent) "Lake Weyto" exists, and Ongota is spoken to the east of Ts'amakko, 2 rather than to the north. The improvement is mostly the result of a single article, published in 1992/93 in

${ }^{1}$ The following abbreviations are used:

$\begin{array}{llll}\text { Amh } & \text { Amharic } & \text { NPST } & \text { Non-Past } \\ \text { CAUS } & \text { Causative verbal extension } & \text { O } & \text { Ongota } \\ \text { F } & \text { Feminine } & \text { PST } & \text { Past } \\ \text { IMPV } & \text { Imperative } & \text { P } & \text { Plural } \\ \text { INF } & \text { Infinitive } & \text { PROG } & \text { Progressive } \\ \text { INT } & \text { Interrogative } & \text { S } & \text { Singular } \\ \text { INTR } & \text { Intransitive verbal extension } & \text { SING } & \text { Singulative } \\ \text { ISP } & \text { Impersonl Subject Pronoun } & \text { Ts } & \text { Ts'amakko } \\ \text { M } & \text { Masculine } & & \\ \text { MID } & \text { Middle verbal extension } & - & \text { Morpheme boundary } \\ \text { NEG } & \text { Negative } & = & \text { Clitic boundary }\end{array}$

2 The denomination of Tsamay or Ts'amay, although common in the area (and in the literature) is unknown in the language itself. The ethnic selfname is rather Ts'amakko (corresponding to S'aamakko of Hayward [1989]). 
the short-lived Journal of Afroasiatic Languages. The article, entitled 'Ongota or Birale: A moribund language of Gemu-Gofa (Ethiopia)', was co-authored by Harold C. Fleming, Aklilu Yilma, Ayyalew Mitiku, Richard Hayward, Yukio Miyawaki, Pavel Mikeš, and J. Michael Seelig [Fleming et al. 1992/93] and presented the first real data on the Ongota language. Actually, as well-argued in the article itself, there are reasons to believe that the Ongota were first mentioned by the American explorer Donaldson Smith [1896], when he spoke of a "Borali" people in connection with other yet unidentified tribes, especially a mysterious group of pygmies, the "Dume".

Fleming et al. [1992/93] is particularly interesting for its rich vocabulary (with comparative notes), but it also presented much grammatical data, al-though only incompletely analysed. A year later it was followed by a precious 320 -item wordlist of Ongota, Arbore, and Ts'amakko, published by the "Survey of Little-Known Languages of Ethiopia" [Dinota \& Siebert 1994]. Although the words were carefully transcribed, no phonological analysis was attempted, and grammatical data was missing. In the following years, Aklilu Yilma, a linguist at Addis Ababa University (and one of the authors of Fleming et al. [1992/93]) collected additional sociolinguistic data on the people, visiting their settlement on various occasions. But no new linguistic data has been provided.

Differently from previous researchers, we more or less stumbled on Ongota while working on another language. On August 18, 2000, in the course of a fieldwork campaign aimed at various Dullay varieties, we stopped in the small town of Weyt'o, just after the bridge on the Weyt'o river, along the road leading from Arba Minch to the Omo. We had heard that a few Ongota were working at the Birale Agricultural Development Corp., a successful cotton company whose head-quarters are located just out of town, and had decided to enquire into the subject with the local manager. Although he could not be of great help (to his knowledge, no Ongota was found among the workers), he had us taken to somebody who arranged to have a few Ongota brought to us. On the following day we were introduced to three ethnic Ongota $^{3}$ and began interviewing them. It soon became apparent that the three had a limited command of the language (although they could remember much of its vocabulary). Finally, we were promised a much better speaker for the following day, and on August 20 we were introduced to Mole Sagane, of the baritto clan.

Mole was the informant who provided Dinota \& Siebert's [1994] word-list (where he is referred to as Moyle Sagane). A short interview convinced us that he was the man we were looking for; Mole agreed to follow us to Jinka (the provincial capital of South Omo), where we worked full-time on Ongota from August 21 to 29. The present article contains the result of that work.

Mole claimed once to be 48 years old (but later denied knowing his age); he is a well-known and much respected elder, as well as a brave hunter; a native speaker of Ongota, he speaks like all his people a perfect Ts'amakko, masters well Hamar-

3 Their names are: Geta K'awla, Muda K'awla, and Gename Wa'do. 
Banna, and has also a working knowledge of both Amharic and Borana Oromo. 4 He soon proved to be a good linguistic informant, intelligent, cooperative and, above all, patient towards our endless questioning and our first clumsy attempts at speaking his language.

According to Mole, there are eight speakers of Ongota left: apart from himself, his older brother Aburre Sagane, and four brothers: Dulo Korayo, Oydalle Korayo, Guya'o Korayo and Iida Korayo (of the Samaddo clan). They all live in Muts'e, a good hour's walk upstream of the bridge upon the Weyt'o river; most Ongota live there, together, we were told, with a few Ts'amakko. Two other Ongota speakers not living in Muts'e are Mole's older brother Tabba Sagane, and Gacco Olle (of the hizmakko clan). According to Mole, the eight speakers actively use the language among themselves (on one occasion, we witnessed a conversation between Mole and one of his brothers).

Mole also claimed that four Ongota women speak the language, but since they are married to Ts'amakko men and have been living among the Ts'amakko for many years, it is probable that their active knowledge of the language is limited. We could not have their names.

The number of the ethnic Ongota is only slightly larger: according to Mole's mental count, they do not exceed one hundred. This accords well with Aklilu Yilma's (p.c.) personal count of 75 Ongota in Muts'e alone, and with the figure of 89 given in Fleming et al. [1992/93: 186]. Many, according to Mole, understand Ongota, some of them also speak it a little bit (such as the three Ongota we met on August 19), but for all practical purposes Ongota is a dead language and the Ongota are Ts'amakko speakers.

Still according to Mole, the Ongota abandoned their language and ceased teaching it to their children in order to avoid being teased by the Ts'amakko and the Banna. But he had to admit that their pastoral neighbors still look upon them in scorn, since the Ongota do not possess cattle and mainly live on fishing, hunting and honey.

We do not take a position on questions of classification in this descriptive sketch; different hypotheses have been put forward about the genetic affiliation of Ongota: that it is an autonomous branch of Nilo-Saharan [Blažek 1991]; that it is a separate branch of Afroasiatic (Harold Fleming), or that it makes a separate branch within South Omotic (Christopher Ehret, p.c.). While either a Cushitic or Omotic affiliation makes sense, one must note that the almost complete absence of inflectional morphology makes Aklilu Yilma's (p.c.) idea of a creolized pidgin attractive, if only, at the present state of our know-ledge, unverifiable. This creole would involve Nilotic, Omotic, and Cushitic elements (Lionel M. Bender, p.c.), because, as Bender [1994] has shown, any statistical test on the basic lexicon does not support aligning Ongota with any single Ethiopian language family. A further element pointing in the direction of a creole is possibly provided by the oral traditions of the Ongota, who speak of themselves as originally a collection of clans from

${ }^{4}$ Due to Mole's insufficient knowledge of Amharic, we were partially helped by Olle Fattale, a Ts'amakko policeman servicing in Jinka. 
different ethnic and linguistic origins (ranging, for example, from the North Omotic Maale to the South Omotic Banna, to the East Cushitic Borana and Dishina).

\section{Phonology}

2.1. Segments. As noted by Fleming et al. [1992/93: 190], any account of the phonology of Ongota (henceforth: $\mathrm{O}$ ) is hampered by the huge amount of free variation which is found in the data. This variation is most probably the result of the obsolescence of the language and of the pervasive influence of Ts'amakko (henceforth: Ts), which, as anticipated, is the true living language of the Ongota. Even when speaking in $\mathrm{O}$, code-switching with Ts is the norm. Also, most phonological processes of $O$ find an exact parallel in Ts (e.g., the Final Height Neutralization of Vowels, the Glottal Onset Insertion, and many others).

The $\mathrm{O}$ vowels are the five cardinals. Their quality is relatively stable and unaffected by neighboring consonants. As for the consonants, $\mathrm{O}$ operates with the 26 phonemes charted in Table 1.

Table 1. The consonant phonemes of Ongota

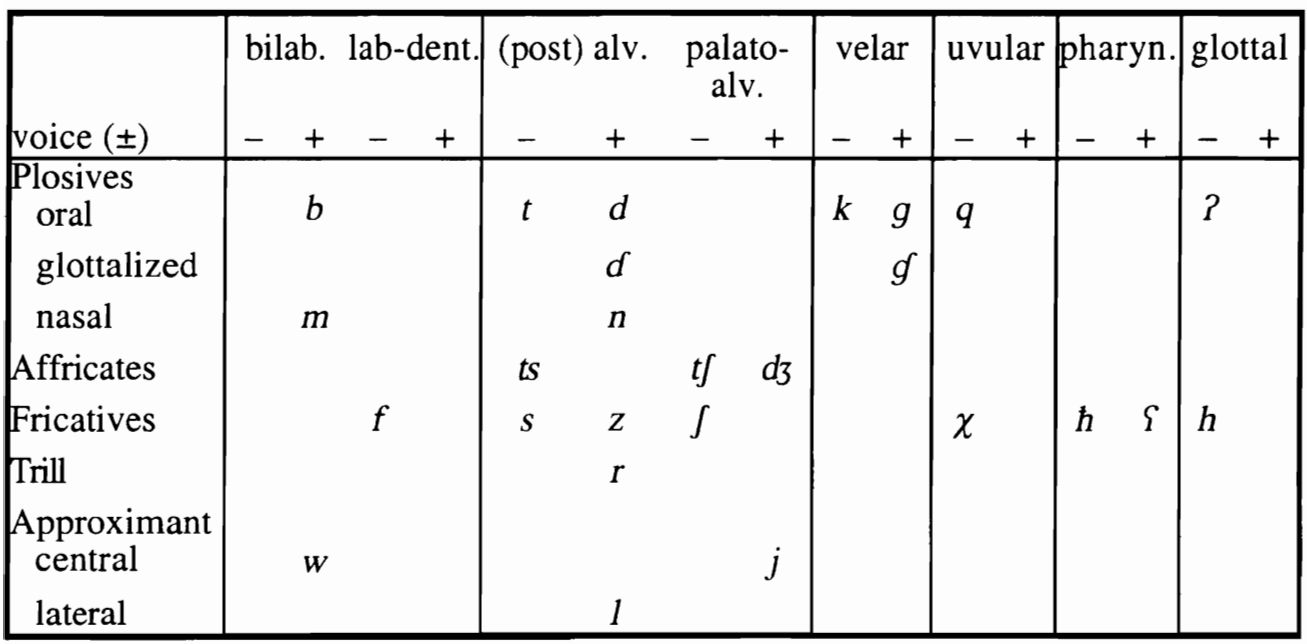

The following spelling conventions are used: IPA $/ \mathrm{J} /=\check{s} ; / \mathrm{d} 3 /=j ; / \mathrm{t} J /=c ; / \mathrm{j} /=y ;|\chi|=x$.

\subsection{Allophonic variation}

2.2.1. Voicing opposition. As for Ts'amakko and other Dullay varieties, as well as the Konsoid languages, the status of the voice-voiceless opposition is doubtful (cf. Hayward [1989: 7-8] for Ts'amakko and Amborn, Minker \& Sasse [1980: 73] for Dullay in general). Voice alternations have been found extensively for $/ \mathrm{h} /$ and $/ \mathrm{s} /$ and, in one case only, between $/ \mathrm{d} /$ and $/ \mathrm{t} /$, as in (1). A word-initial $/ \mathrm{t} /$ is often voiced into [d] when it comes to be found between vowels, for example, in cliticization, as in (2). 


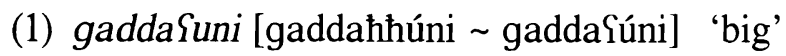

gidata [gidáta gitáta] 'you (P)'

(2) miditte 'clitoris' but miditti=du (an insult; from miditte=tu)

2.2.2. Labial alternation. In a few cases $\left[\mathrm{p}^{\mathrm{h}}\right]$ is in free alternation with /f/.

(3) oxoni fa?o [pá?o] 'to kindle the fire'

Word-internally /bb/is optionally devoiced to $\left[\mathrm{pp}^{\mathrm{h}}\right]:[\mathrm{bb}] \rightarrow\left[\mathrm{pp}^{\mathrm{h}}\right] / \mathrm{X}-\mathrm{X}$

(4) dibba [dípp $\left.{ }^{\mathrm{h}} \mathrm{a}\right]$ 'hundred'

abba [app $\left.{ }^{\mathrm{h}} \mathrm{a}\right] \quad$ 'good'

In Ts, too, $/ \mathrm{p} /$ is in free alternation with $/ \mathrm{p}^{\mathrm{h}} /, / \mathrm{f} /$ or $/ \phi /$ in all positions, except when geminated or postnasal [Hayward 1989: 5]: for example, pari [pari fari] 'to die' and poolo [po:lo $\sim$ p $^{\mathrm{h}}$ : lo $\sim \phi$ o:lo] 'cloud'.

2.2.3. Fricativization. The palato-alveolar voiced affricate optionally loses its stop component, becoming a fricative. Again, this process occurs also in Ts: [d3] $\rightarrow[3]$ (optional).

(5) janta [dzánta zánta] 'you' (S)

2.2.4. Glottalization. There is no plain (non-glottalized)/ts/ in Ts; the phoneme Hayward [1989] transcribes $/ \mathrm{s} \%$ "is usually an affricated (but occasionally a fricative) ejective" ([Hayward 1989: 6]; hence Hayward's "S' aamakko" for the more common "Ts' aamakko" or "Ts' amakko"). In O, on the contrary, /ts/ is plain; glottalization is frequently heard in Ts loans (e.g., tsoonako [ts'o:náko] 'honeybee') and sporadic elsewhere, for example, nitsina [nits'ina] 'many').

Likewise, the phonemic status of glottalized /c'/ [t]'] vs. plain /c/ is doubtful: both phonemes are found in Ts (although the latter is rare [cf. Hayward 1989: 5]); in $\mathrm{O}, / \mathrm{c}$ '/ has been recorded only in a few Ts loans, such as cayde [t $\mathrm{t}$ 'ájde] 'pen, enclosure', but also in the possibly native word conqorte [t]'onqórte] 'mud'.

\subsection{Phonological processes}

2.3.1. Final Height Neutralization. Word-finally only three vowels are in opposition, the high vowels $/ \mathrm{i}$, $\mathrm{u} /$ being optionally lowered to mid /e, o/:

$$
\mathrm{V}_{\text {[+high] }} \rightarrow \mathrm{V}_{\text {[-high, -low] }} / \text { _\# (optional). }
$$

(6) $k i=[\mathrm{ki} \sim \mathrm{ke}] \quad$ '3S.M' (3rd Singular Masculine, Subject Clitic)

The same neutralization is common in Ts, not only in final position, for example, geSe [géY'e géS'i] 'belch' and kuttonko [kuttónko kottónko] 'mountain'. 
2.3.2. Final-Vowel Dropping. A final /a/ is often dropped in connected speech and before clitics. Other final vowels are not apparently affected. This process is reminiscent of similar rules dropping a "Terminal Vowel" (generally, a lexicalized former gender marker) in neighboring Cushitic languages (cf. Tosco [2001: 65f.] for Dhaasanac). 5
(7)

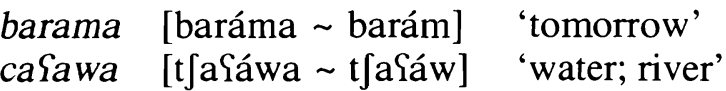

2.3.3. Glottal-Onset Insertion. The phonemic status of $/ \mathrm{h} /$ is doubtful: on the one hand, a handful or so of words are consistently pronounced with an initial $/ \mathrm{h} /$; a few examples are: handura 'navel', hobat-'to wash', and the Ts loan hokam-'to exchange'. In all these cases, $/ \mathrm{h} /$ is considered phonemic. On the other hand, vowel-initial words are optionally provided with a glottal onset, and (possibly as a result of the uncertainties in voicing opposition [cf. 2.2.1.]) this is realized either as a glottal stop [?] or as a voiceless laryngeal [h] in free variation:

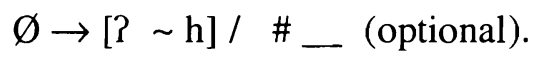

(8) ayma [áyma Pájma hájma] 'woman'

In Ts, too, apparently there is free alternation between $\varnothing$ and / $/$ word-initially, for example, arre [?arre arre] 'donkey', although the phonemic status of $/ \mathrm{h} /$ is beyond doubt.

2.3.4. Final-Glottal Deletion. The presence of $/ R /$ in word-initial position is due to the operation of Glottal Onset Insertion (cf. 2.3.3); $/ \mathrm{R} /$ is, nevertheless, phonemic in word-internal position (although attested in very few words only, such as ii?a 'arm'). A glottal stop is deleted word-finally, but it is recovered in affixation, for example, [ki=d3í] 'he killed, hit' will be interpreted and transcribed $k i=j i 1$, on the basis of such forms as the IMPV.S: jiPá 'kill!' and the IMPV.P: jîta 'kill! (P)'. Final Glottal Deletion $(/ P / \rightarrow \varnothing / \ldots$ _ is particularly relevant in Middle verbs, whose extension $=i$ i is realized as [i], except when further followed by an affix, as shown by the examples in (9).

5 The label "Terminal Vowel" itself is taken from Hayward's [1987] discussion of Ometo nominals, where it is used in a different technical meaning. 

(9) fa?-
'to kindle; add; put into' fa?á
IMPV.S: $\quad$ IMPV.P:

compare also the derived forms:

$\begin{array}{clll}\text { fa?i?- } & \text { 'to add for oneself' } & \text { fa?i?á } & \text { fa?i?tá } \\ \text { fa?san- 'to make add' } & \text { fa?saná } & \text { fa?sánta } \\ \text { romi?- 'to converse' } & \text { moromi?á } & \text { moromí?ta }\end{array}$

[moromi]

$\begin{array}{llll}\text { ta?- } & \text { 'to take, catch' } & \text { ta?á } & \text { tá?ta } \\ \text { tu?- } & \text { 'to put into (sth. solid)' } & \text { tu?á } & \text { tú?ta } \\ \text { xo?- } & \text { 'to beat, hit' } & \text { xo?á } & \text { xó?ta } \\ \text { zoo?- } & \text { 'to take honey' } & \text { zoo?á } & \text { zóo?ta }\end{array}$

2.3.5. Final Devoicing. Voiced plosives are devoiced word-finally.

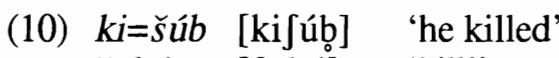
šubá [Jubå] 'kill!'

The voiced affricate is devoiced, not only word-finally, but also, optionally, word-internally: /d $3 / \rightarrow / \mathrm{t} \int /$ (optional).
(11) ka=báaj [kabá:t]] 'I carried'
báajjo [bá:t]:o] 'to carry'

The same optional devoicing occurs in Ts, too, for example, ji؟So [dziS':o 3iऽ':o] 'a sp. of bird'.

2.3.6. Final Non-release. Final voiceless plosives are unreleased.

(12) $k i=c a ́ k \quad$ [kit]ák'] 'he ate' compare: caká 'eat!'

A particular application of Final Non-release is the dropping of a word-final glottal stop (Final Glottal Deletion, cf. 2.3.3).

2.3.7. Uvular Spirantization. The uvular stop is generally voiced and fricativized intervocalically: $\mathrm{q} \rightarrow[\mathrm{\textrm {B }}] / \mathrm{V} \_\mathrm{V}$, as in (13). Word-finally, it can be affricated (14).

(13) kata kara $k a=q a ́ f i \quad$ [kasáfi] 'I fished'
I fish $1 \mathrm{~S}=$ catch.PST

(14) $k i=c o ́ q$

3S.M=shoot.PST

[kitfóq $\chi \bar{\chi}]$ 'he shot'

Intervocalic uvular spirantization occurs in Ts, too, as, for example, in soqo [sово] 'salt'. 


\subsection{Assimilations}

2.4.1. Assimilation to a dental. The Imperative Plural suffix -ta induces progressive voicing assimilation of an immediately preceding voiced plosive.
(15)
yeqadá
'hiccup!'
'sniff!' sugá
yeqadtá [yeqattá]
súgta [súkta]

IMPV.P

2.4.2. Nasal Assimilation. A nasal assimilates to the articulation point of a following plosive.
(16) $k i=i f a m$
'he married'
ayma $=k o$ kita ífan $=t a$ 'the woman he married'
(17) tagamá 'sleep!'
tagánta (IMPV.P)

2.4.3. Sibilant harmony. $/ \mathrm{s} /$ of the Causative suffixes $=s a n,=a s,=i s$ becomes a palato-alveolar $/ \bar{s} /$ when following a palatal consonant in the stem.
(18) $k a=c o ́ q$ 'I shot'

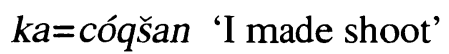

In Ts, /s/ of the causative suffixes -is, -as and the rarely attested -os is affected by the same kind of sibilant harmony (19).
(19)

$\begin{array}{llll}\text { jooq }-i & \text { 'I/he ground' } & \text { jooq-aš- } i & \text { 'I/he made grind' } \\ \text { šoh-i } & \text { 'I/he washed' } & \text { šoh-iš-i } & \text { 'I/he wade wash' } \\ \text { šiggar-i } & \text { 'I/he stopped' } & \text { šiggar-oš-i } & \text { 'I/he made stop' }\end{array}$

In O., the same rule has been sporadically found in other cases, as in (20).
šijju
'by us, chez nous'
$\left({ }^{*}\right.$ sijju)

2.5. Syllables. The syllable structure of $O$ can be expressed as $(C) V(V)(C)$. This allows the following syllable types:

\begin{tabular}{|c|c|c|c|}
\hline V & as in: & á́.xa.co & 'sun' \\
\hline $\mathrm{CV}$ & & ca.ta & 'meat' \\
\hline CVV & & $\underline{\text { zoo. }} \cdot b a$ & 'beeswax' \\
\hline $\mathrm{VC}$ & & ip.pa & ‘door’ \\
\hline VVC & & iiš.te & 'neck' \\
\hline $\mathrm{CVC}$ & & $(k a=) \underline{\text { cóq }}$ & 'I shot' \\
\hline CVVC & & ( $k a=$ )tíid & 'I put' (past) \\
\hline
\end{tabular}

2.6. Clusters and epenthesis. Clusters are limited to two elements and to wordinternal position. A three-element cluster arising from affixation processes is 
avoided through epenthesis of /i/ after the second member. That the affricates /ts/, $/ \check{c} /(=[\mathrm{t}]])$, and $/ \mathrm{j} /\left(=\left[\mathrm{d}_{3}\right]\right)$ are single segments and not sequences of a plosive and a fricative is shown by the fact that a following segment does not yield epenthesis.

(21) tuuts-'to push' IMPV.S: tuutsá

IMPV.P: $\quad$ túutsta $\left({ }^{*}\right.$ túutsita)

2.7. Length. Vowel length and intervocalic consonant gemination (both marked by doubling of the relevant symbol) are phonemic.

$\begin{array}{rlll}\text { (22) aka 'foot, leg' } & \text { aaka } & \text { 'women, females' } \\ \text { aka } & \text { 'foot, leg' } & \text { akka } & \text { 'grandfather' } \\ \text { ame- } & \text { 'to suck' } & \text { aame- } & \text { 'to rest' }\end{array}$

Certain affixes involve the gemination of a preceding consonant, such as the infinitive affix $=C o(23)$. Again, the same rule affects the infinitive suffix $-o$ in Ts, as in (24).

(23) dim- 'to plunge' > dimmo

kat- 'to come out' > kátto

(24) $k o$ ?-i 'I/he burned'; ko?-?o

deh-i 'I/he gave'; deh-ho 'to plunge' (Infinitive)

'to come out' (Infinitive)

'to burn' (Infinitive) (Ts)

'to give' (Infinitive) (Ts)

2.8. Suprasegmentals. Accent is defined here as an abstract property of morphemes to be able to carry high pitch. The presence of accent is marked by $/ /$ and is contrastive.

(25) yooba [yó:ba] 'men, males'

yoobá [yo:bá] 'see!' (IMPV.S)

(in the first case, accent is placed upon the first mora by default (see below); in yoobá, the stem yoob- is followed by the morpheme of the Imperative Singular (Positive) -á, which bears inherent accent.)

The accent-bearing unit is the syllable, but, on long vowels, accent may fall either on the first or the second mora. A sequence / $v$ v/ is phonetically realized as a long falling tone; conversely, a sequence / $v$ v́/ is phonetically realized as a long rising tone. Falling and rising tones, being predictable, are not marked in the transcription.

Opposition between a falling and a rising tone may be seen in the Past vs. NonPast of verbal stems of shape CVVC (cf. 3.9.3).

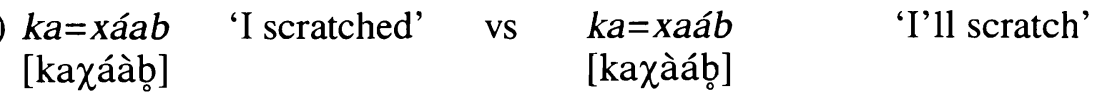


Accent may be lexically or morphologically defined, or may be assigned by default. In this case, it affects the penultimate syllable. Default-assigned accent is not marked in the phonological transcription.
gitata [gitáta] 'you (P)'
kara [kára] 'fish'

Penultimate position is the rule for accent placement also in plurimorphemic words resulting from the affixation/cliticization of accentless morphemes.
(28)
ayma [ájma] 'woman',
Songota [Songóta] 'Ongota'
ayma =ko [ajmáko] 'the woman' Songotitta [Songotitta] 'one Ongota'

Morphologically-assigned accent is found in verbs (cf. 3.9.3), where past is expressed by accent on the first (in the following example, the only) stem vowel, while non-past is expressed by absence of accent on the stem vowel, which induces high pitch on the subject clitic ka.
(29)
$k a=c o ́ q$ [kat $[o ́ q] \quad$ 'I shot'
$k a ́=\operatorname{coq}[$ kát $[o q]$
'I'll shoot'

Accent may be assigned lexically, either on the antepenultimate (for example, Sádaba 'tongue') or on the last mora (for example, barám 'tomorrow' in alternation with barama [baráma]).

Accent may also be assigned lexically to specific morphemes, such as the Imperative Singular -á or the Imperative Plural ${ }^{\prime}$-ta (which induces accent on the preceding vowel).
(30) coqá 'shoot!'
cóqta 'shoot!' (P)

2.9. Treatment of Ts'amakko loans. Borrowings from Ts are often left unchanged. However, a final /o/ of Ts is often changed into /a/ in $\mathrm{O}$, especially in the Singulative suffixes (cf. 3.2.1.1), as in (31). There are, nevertheless, many exceptions, as in (32), which are perhaps to be regarded as unassimilated loans. A similar change of Ts final /e/ to $\mathrm{O} / \mathrm{a} /$ is also common, shown in (33).

(31)

$\begin{array}{lll}\begin{array}{l}\text { Ts'amakko } \\ \text { irgaSo }\end{array} & \begin{array}{l}\text { Ongota } \\ \text { irgaSa }\end{array} & \text { 'axe' } \\ \text { orgo } & \text { orga } & \text { 'Hamer-Banna' } \\ \text { baaro } & \text { baara } & \text { 'armpit' } \\ \text { barlo } & \text { barla } & \text { 'white-browed sparrow weaver' } \\ \text { heko } & \text { hooka } & \text { 'chest' (note the irregular vowel change) } \\ \text { rummaStitto } & \text { rummaStitta } & \text { 'an Arbore man/woman' } \\ \text { orgitto } & \text { orgitta } & \text { 'a Hamer-Banna man/woman' } \\ \text { konsitto } & \text { konsitta } & \text { 'a Konso man/woman' } \\ \text { kaykitto } & \text { kaykitta } & \text { 'male guest' }\end{array}$




\section{Ts'amakko Ongota}

(32) boraho

(33)

$\begin{array}{lll}\text { atole } & \text { atolla } & \text { 'pigeon' } \\ \text { dige } & \text { diga } & \text { 'owlet' } \\ \text { donke } & \text { donka } & \text { 'hornbill' } \\ \text { hezze } & \text { hizza } & \text { 'root, vein' } \\ \text { biye } & \text { biya } & \text { 'earth, land' } \\ \text { kirince } & \text { kirinca } & \text { 'ankle' } \\ \text { kurrube } & \text { kurruba } & \text { 'crow' }\end{array}$

In a few cases a Ts noun extended with a lexicalized Singulative suffix has been taken into $\mathrm{O}$ in its bare form, possibly from an earlier stage of Ts; in most such cases the $\mathrm{O}$ word ends in /a/ (34); a few end in /o/ (35). There are a few cases of irregular change in the final vowel or the suffix (36).

(34)

$\begin{array}{ll}\text { berko } & \text { bera } \\ \text { do?osko } & \text { do?osa } \\ \text { dullayko } & \text { dullaya } \\ \text { gereSko } & \text { gereSa } \\ \text { gibilko } & \text { gibila } \\ \text { gubusko } & \text { gibisa } \\ \text { gaarakko } & \text { gaara } \\ \text { damSatto } & \text { dam§a } \\ \text { qalatte } & \text { qalaya }\end{array}$

(35) halte

balgitto

(36) gogile

tokonko

kormicco halo

balgo

goga

tokoma

korome 'season'

'waterbuck'

'the Weyt'o river' 6

'thief'

'knee'

'femur'

'monkey'

'giraffe'

'hyena'

The / $/$ / of Ts loanwords is sometimes devoiced to $/ \mathrm{h} /$ (cf. 2.2.1. for Voicing Opposition in O) (37). A cluster / $/ \mathrm{t} /$ in a Ts loan is shifted to /tt/ in $\mathrm{O}$ (38).

(37) Saaško

Sangararo

(38) oršaSte

muqoite haaše

hangararo

oršatte

muqotte 'grass'

'worm'

'rhinoceros'

'frog'

6 From the local name of the Weyt'o river Amborn, Minker \& Sasse [1980] originally proposed to call "Dullay" an East Cushitic dialect cluster spoken on both sides of the river (with Ts'amakko being spoken on the west side, and all the other dialects on the highlands to the east). 
Finally, the following kinship names are extended in $\mathrm{O}$ with -ne.

(39) Ts'amakko Ongota

Sazo Sazane

šałalko šałalkune 'younger brother'

'older brother'

2.10. Words, affixes and clitics. A word is defined here phonologically as the domain of accent placement (cf. 2.8). A word may be mono-morphemic (as is most commonly the case of nouns), or it may be formed by a root morpheme followed by one or more affixes (for example, verbal forms, which are always at least bimorphemic), or, still, by a stem preceded and/or followed by one or more clitics:

$$
\text { Word }=\left(\text { Clitic }_{n}\right)+\text { Stem }+\left(\text { Affix }_{n}\right)+\left(\text { Clitic }_{n}\right)
$$

A few examples displaying different word-compositional possibilities are shown in (40).

\begin{tabular}{|c|c|}
\hline (40) ayma & 'woman' (monomorphemic) \\
\hline sugá & 'sniff!' (stem sug-'to sniff' + IMPV.S. Suffix -â) \\
\hline coqšaná & $\begin{array}{c}\text { 'make shoot!' (stem coq-'shoot' + Causative suffix -san } \\
\text { + IMPV.S. Suffix -â) }\end{array}$ \\
\hline$a y m a=k o$ & ayma + Determinative clitic $=k o$ \\
\hline$k a=$ & $\begin{array}{c}\text { 'I shot' }(k a=\text { '1st Sing. Subject Clitic' + stem coq-'shoot } \\
+ \text { Past } / / /)\end{array}$ \\
\hline
\end{tabular}

\section{Morphology}

3.1. Word-classes. Nouns and verbs may be clearly defined in $O$ in terms of their different morpho-syntactic behavior. Other categories of less certain status are the adpositions, the pronouns, the adjectives, and the numerals.

3.2. Nouns. Native nouns are uninflected, apart from the occasional use of Ts number (both Singulative and Plural) suffixes. In one case, from the native noun caSa 'stone' a diminutive has been provided through a change in vowel quality: cefe 'pebble'.

Nouns always end in a vowel (verbal stems, on the contrary, are generally consonant-ending); the preferred word shapes are (C)V(V).CV or (C)V(V).CV. CV. The final vowel is subject to deletion when a Ts number suffix is added.

A few nouns are apparently related to verbal stems, in a few cases through the addition of a vowel copying the (last) stem vowel of the verb. dayte 'firestick' is apparently a borrowing from Ts dayte, but compare the verb day-'to twist'. 


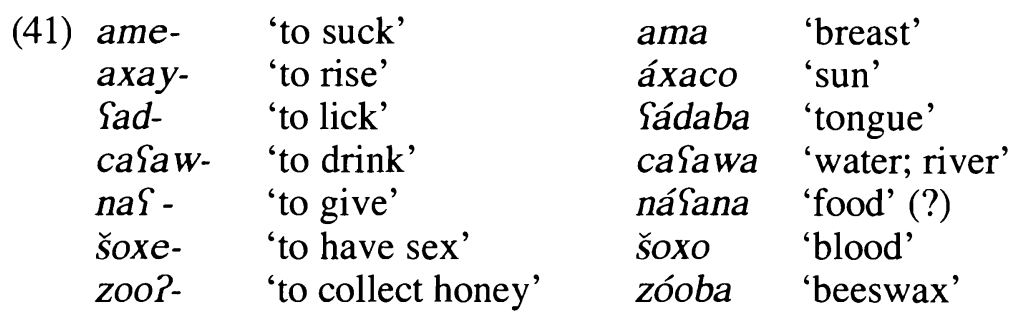

\subsubsection{Number}

3.2.1.1. Singulative. Names of peoples (all of them apparently Ts loans, except fuga 'Amhara') have a collective meaning; from them singulative forms are built through the suffixes -itta (M) and -itte (F), corresponding to Ts -itto (M) (cf. 2.9) and -itte $(\mathrm{F})$, respectively.

(42)

fuga
orga
(cf. Ts orgo
rummatte
(cf. Ts rummaite
Sale
(cf. Ts Salle
konso
Songota
(cf. Ts Songota

S.M fugitta

S.M orgitta

S.M orgitto

S.M rummattitta

S.M rummaStitto)

S.M Salitta

S.M Sallatto)

S.M konsitta

S.M Songotitta

S.M Songotitto)
'Amhara'7

S.F orgitte 'Hamar-Banna'

S.F orgitte)

Examples of the use of the singulative forms (43)-(44) vs. plural (45):

(43)

(44)

(45)
'I am Ongota' (focalized; cf. 4.11)

'the woman is Ongota'
Gawwada and other Dullayspeaking groups of the highlands

'Konso'

'Ongota' 
suffix -te has been used with the $\mathrm{O}$ word ceSe 'pebble' with a diminutive meaning, yielding ceYete 'pebble'.

(46) Masculine Singular

zaarakko
kamurko
daafakko
arrakko
tonnakko

Feminine Singular zaaratte

kamurte

daafatte

arratte

tonnatte
Plural

$\begin{array}{ll}\text { zaarayke } & \text { 'fool, crazy' } \\ ? & \text { 'rich' } \\ \text { daafayke } & \text { 'blind' } \\ \text { arrayke } & \text { 'dark grey' } \\ \text { tonnayte } & \text { 'lame' }\end{array}$

3.2.2.2. Plural and Collective. A common way to express plurality is through the use of the adjective badde 'all' or nitsina 'many' (47). Occasionally, the Ts plural affix $=a d d e$ is used with $\mathrm{O}$ nouns. A frequent case is Sádiba 'elder', which is often provided a plural form Sadibadde, perhaps because other nouns referring to groups of people express number distinctions through the use of different stems, as in (48).

$$
\begin{aligned}
& \text { ayma=ko badde 'all the women' } \\
& \text { woman-DET all }
\end{aligned}
$$

(48)

\begin{tabular}{lll} 
Singular & \multicolumn{2}{l}{ Plural or Collective } \\
ayma & aaka & 'woman; female; wife' \\
inta & yooba & 'man; male; husband' \\
jaaka & eela & 'child, baby' \\
juuka & igire & 'girl; daughter' \\
maara & eela & 'boy; son'
\end{tabular}

In a few cases (49), the element - wa has been observed with a plural function. It might be an old Plural marker fallen out of use.
(49) Songotawa
karawa
'Ongota' (P)
juukawa
'fishes'
'girls'

3.2.2. Gender. Apart from the occasional use of different gender-sensitive Singulative suffixes, gender is not formally expressed on O nouns. Nominal gender has nevertheless relevance in the pronominal system and in verbal accord. In the Personal Pronouns different forms for the 3rd Sing. Masculine and Feminine are used. Gender accord with subject nouns denoting humans is natural; with subject nouns denoting things the Subject clitic is in the 3S.F, and the same applies to most animals, especially little and socially unimportant ones (for example, most wild animals). 
(50) uke $\quad k i=t i ́ b$

elephant 3S.M-die.PST

'an/the elephant died'

vs.

(51) karbo $k u=t i ́ b$

bird 3S.F-die.PST

'a/the bird died'

3.3. Pronouns. The Personal Pronouns of $O$ follow the usual Cushitic sevenmembers system, with separate Masculine and Feminine elements for the 3rd Singular.

Six series of personal pronominal elements have been identified: Emphatic, Subject Clitic, Object, Postpositional, and Possessive; a sixth series, the Indirect Clitics, has separate forms for the singular persons only. They are shown in Table 2 , together with their glosses.

Table 2. Personal Pronouns

\begin{tabular}{|c|c|c|c|c|c|c|c|c|c|}
\hline \multicolumn{2}{|c|}{$\begin{array}{c}\text { EMPHATIC } \\
\text { (INDEPENDENT) }\end{array}$} & \multicolumn{2}{|c|}{$\begin{array}{l}\text { SUBJECT } \\
\text { CLITIC }\end{array}$} & \multicolumn{4}{|c|}{ OBJ / INDIRECT / POSTPOS } & \multicolumn{2}{|c|}{ POSSESSIVE } \\
\hline kata & I & $k a$ & $1 S$ & $k a$ & na & ka & me & sinne & my \\
\hline $\begin{array}{l}\text { janta } \\
\text { jaama }\end{array}$ & you & $i$ & $2 S$ & jami & jata & jan & you & siidu & your \\
\hline kita & he & $k i$ & 3S.M & $k i$ & wana & $k i$ & him & seena & his \\
\hline kuta & she & $k u$ & 3S.F & $k u$ & wata & $k u$ & her & suu?u & her \\
\hline juta & we & ju & $1 \mathrm{P}$ & $j u$ & - & $j u$ & us & sijju & our \\
\hline gitata & you & gita & $2 \mathrm{P}$ & gita & - & gita & you.Obj & sigida & your \\
\hline ki?ita & they & ki?i-a & $3 P$ & $\begin{array}{l}\text { kiPi } \\
\text { kiPa }\end{array}$ & - & $k i ? i$ & them & suwaya & their \\
\hline
\end{tabular}

3.3.1. Emphatic Pronouns. Emphatic pronouns may occur in whatever syntactic role but do not replace members of the other series. They may be regarded as extrasentential. In the following sentence the Emphatic pronoun is underlined.

(52)

¿uta hanca ju=gád

we tree 1P-cut.PST

'we cut the tree'(past)

3.3.2. Subject Clitics. The Subject Clitics obligatorily precede the verbal form in declarative clauses. The Impersonal Subject Pronoun a (ISP), which is used in the Passive (cf. 4.3.3), also belongs here. In the following sentence the Subject Clitic is underlined.

(53) janta hanca $\underline{i}=$ gád you tree 2 S-cut.PST

'you cut the tree'(past) 
3.3.3. Object Pronouns. The Object Pronouns (underlined in the following examples) are used in the role of direct objects; they may appear before the Subject Clitic but may also be cliticized after a verbal form.

(54) kata $\underline{\text { i }}$ ka=góhis

I him 1S-make_grow.PST

'I made him grow'

(55) kata šu?una $=m e ~ k a=s ̌ u ́ g u c=\underline{k i} \quad$ 'I smeared him with butter'

I butter-with 1S-smear.PST-him

3.3.4. Indirect Pronouns. A series of Indirect Pronouns is proposed on the basis of a few sentences only, in which the 3S.M and 3S.F have irregular forms wana, wata (reported also by Fleming et al. [1992/93: 198]), 1S na, and 2S jata. na and ta as markers of 3S.M and 3S.F, respectively, are found in relative clauses (see 4.7).

For the plural persons the Object Pronouns are used followed by the postposition $=k u$ 'for'. The Indirect Pronouns can appear either before or after the verbal form, as in (56)-(57).

(56) hálo=ke Sari uccé wana 'fill the container with coffee for him!' container-in coffee put.IMPV.S him

(57) barama tora ká=naS jata 'tomorrow I'll give you my spear' tomorrow spear 1S-give.NPST you

3.3.5. Possessives. As expounded in 3.3.6, the Possessive pronominal series may possibly be analyzed as containing the preposition se 'of' followed by a special series of pronominals, also occurring with the preposition $u k u=$ 'on'. The Possessives act as nominal modifiers but may also occur alone.

(58) ayma sinni seena=tu abba woman my his-from good

'my wife is more beautiful than his'

3.3.6. Postpositional series and other pronominals used with adpositional elements. The Postpositional Pronouns are used with a following postposition (see $3.5)$. With the preposition $u k u=$ 'on', which is apparently used only with pronominals, the pronominal element follows in a special form. This same form is also found in the Possessives, which may be analyzed as formed with the preposition se (found, albeit not regularly, in nominal phrases; see 4.2).

The pronominal series used with all the postpositions, the one used with $u k u=$ 'on', and the Possessives are shown in Table 3. Use of the preposition $u k u=$ is shown in (59)-(65).

(59) $u k u=n i k i=$ déhad

on-me 2S.M.come_near.PST

'he came near ("upon") me' 
Table 3. Postpositional Pronouns

\begin{tabular}{|c|c|c|c|}
\hline & Pronouns $+=t u$ 'from' & $u k u=$ 'on' + Pronouns & $\begin{array}{c}\text { Possessives } \\
(s e \text { 'of' + Pronouns) }\end{array}$ \\
\hline $1 \mathrm{~S}$ & $k a=t u$ & $u k u=n i$ & sinni \\
\hline $2 \mathrm{~S}$ & $j a n=t u$ & $u g u=d u$ & siidu \\
\hline 3S.M & $k i i=t u$ & eke $=n a$ & seena \\
\hline 3S.F & $k u u=t u$ & $u k u=? u, u k u=w i$ & suu?u \\
\hline $1 \mathrm{P}$ & $j u=t u$ & $u k u=\check{s} i j j a$ & sijju \\
\hline $2 \mathrm{P}$ & gida $=t u$ & $u k u=$ gida & sigida \\
\hline $3 P$ & $k i P i=t u$ & $u k u=$ waya & suwaya \\
\hline
\end{tabular}

(60) kata ka=dehád ugu=du 'I am coming near ("upon") you' I 1S-come_near.NPST on-you

(61) eke=na dehadá on-him come_near.IMPV.S

'go near him!'

(62) $u k u=? u$ dehadá

on-her come_near.IMPV.S

'go near her!'

(63) janta $u k u=\breve{s i j j a ~} \sim u k u=\check{s} i j j i$ i=déhad 'you came near us' you on-us 2S.come_near.PST

(64) kata uku=gida ka=déhad I on-you.OBJ 1S.come_near.PST

'I went near you (P)'

(65) kata $u k[u]=$ waya $k a=d e ́ h a d$

'I went near them' I on-them 1S.come_near.PST

The following sentences show the use of the Postpositional Clitics with the postposition $=k i$ 'in, to'.

(66) kata gida $=k i \quad k a=$ déhad

I you.OBJ-to $1 \mathrm{~S}$-come_near.PST

'I went near you (P)'

(67) janta ju=ki i=déhad you us-to 2S-come_near.PST

'you came close to us'

When one leaves out of consideration the irregular and defective Indirect Object series, it becomes obvious that the pronominal series share a common set of forms, and that this series actually coincides with the Postpositional Series. In particular, both the Subject and the Object Clitic series are actually identical to the Post- 
positional series, with the exception of the $2 \mathrm{~S}$ Subject Clitic $i$ and the $2 \mathrm{~S}$ Object Clitic jami, while the Emphatic pronouns may be analyzed as formed through affixation of an invariable element -ta of unclear value. 8

3.4. Deictics and Determiners. The deictic system of $O$ is still far from clear. The elements $=k o$ and $=n k i$ (the former very possibly borrowed from Ts'amakko; $\mathrm{cf}$. 3.2.1.1. on Singulatives) are frequently found, with no apparent difference in meaning. Both =ko and =nki will be glossed "Det" (for Determiner); an alternative analysis could account for these elements as connectors, as they are generally found with nouns which are further followed by a modifier, following the pattern common in Ts'amakko and generally in Dullay:

(68) ayma=ko, inta=nki 'the woman, the man' woman-DET, man-DET

More clearly deictic is inda 'this', which follows the noun, either in its bare form or, more commonly, with the Determiners $=k o$ and $=n k i$.

(69) cawo inda ka=héeni

'I like this gun'

gun this $1 \mathrm{~S}$-like.PROG

(70) $a y m a=n k i \quad$ inda $a b b a$

'this woman is beautiful' woman-DET this beautiful

Other deictic words are áddate 'there' (implying a considerable distance from the speaker and the hearer) and inkena 'here (for Masculine nouns)/inkona (for Feminine nouns - females, animals, and things), possibly to be analyzed as plurimorphemic: $i n=k e / k o=n a$, with $=k e,=k o$ being the 3S.M and 3S.F Object Clitics, respectively. Both áddate and $i n=k e=n a / i n=k o=n a$ follow a noun, generally with the Determiners $=k o$ and $=n k i$.

(71) maara=nki áddate sae

'whose is that (faraway) child?'

child-DET there whose

(72) maara=ko inkena sae

'whose is this child (nearby)?'

child-DET here.M whose

(73) tagara inda áddate ka=héeni shade this there 1S-like.PROG

'I like that place' ("shade")

(74) tagara inda in=ko=na $k a=h e ́ e n i$ shade this here-F 1S-like.PROG

8 It is noteworthy that a similar element is found in Omotic languages, most notably in the $1 \mathrm{~S} *$ ta, which Bender [2000: $197 \mathrm{ff}$ ) proposes to explain on the basis of an old affixed copula; in due time the original pronominal element was dropped and its function was taken over by the erstwhile copula itself. 
3.5. Adpositions. Adpositions are clitics to a preceding element, either a noun, a noun modifier, or a pronoun.

$=t u$ 'from'

(75) haw=tu éeni 'where do you come from?'
where-from come.PROG

(76) Songot=tu $k a=e ́ e n i \quad$ 'I came from Ongota' Ongota-from $1 S$-come.PROG

(77) kata caYáw=tu katto ka=háabini 'I want to come out of I water-from come_out.INF 1S-want.PROG the water'

(78) $k a=t u$ eefi $k u=k u ́ m \quad$ 'I finished the milk' me-from milk 3S.F-finish.PST

The postposition $=t u$ may also follow a Possessive pronominal with a spatial meaning ('by', Fr. 'chez').

(79) $s i j j i=t u \quad$ maara xódi our-from child be_born.PST

'a boy was born to us'

Noteworthy is also the use of $=t u$ in insults, such as in sorra $=d u$ from sorra 'anus' (see also the lexicon; note also the intervocalic voicing of $=t u$ to $=d u$; see 2.2.1).

$=k i$ 'to, in' (movement):

(80) haw=ki i=róota

where-to $2 S$-go.PROG

'where are you going?'

(81) Songot=ki ka=róota

Ongota-to 1S-go.PROG

'I am going to Ongota'

(82) kata caYáw=ki réehu $k a=\hbar a ́ a b i n i$

I water-to go_down.INF 1S-want.PROG

'I want to go in the water'

(83) halo=ke Sari $u c c e ́=j u=k u$

'fill the container with coffee for us!' container-in coffee put.IMPV.S-us-for

$=m e$ ' $w i t h$ ' (instrumental and comitative)

(84) hak=me gida=éeni who-with 2P-come.PROG

(85) kata cawo=me binta ka=hát I gun-with animal 1S-shoot.PST

'who did you (P) come with?'

'I shot the animal with the gun' 
(86) inta gúlbata $=m i \quad k i=$ dángadi man strength-with 3S.M-work.PROG

'the man is strong' ["works with strength"]

$=k u$ 'for' (also used to express an indirect object with nominals and, as anticipated in 3.3.4., with plural pronouns)

(87) halo=ke Sari ka=úcci gida $=k u$ container-in coffee 1S-put.PST you.P-for

'I filled the container with coffee for you (P)'

["I put coffee in the container for you"]

(88) halo=ke Sari uccé ju=ku container-in coffee put.IMPV.S us-for

'fill the container with coffee for us!'

=na 'with, and'

(89) caYáw=na eefi ella ki= Sángata water-and milk together 3S.M-mix.PST

'he mixed water with milk'

(90) halo=ke Sari uccé na container-in coffee put.IMPV.S me

(91) halo=ke Sari uccé waya $=k u$ container-in coffee put.IMPV.S them-for

'fill the container with coffee for me!'

'fill the container with coffee for them!'

(92) halo=ke Sari ka=úcci ja=ta container-in coffee 1S-put.PST you-for

'I filled the container with coffee for you'

(93) halo=ke Sari ka=úcci=wa=ta container-in coffee 1S-put.PST-her-for

'I filled the container with coffee for her'

3.5.1. Spatial relations. A few items, possibly nouns, which follow a noun to which the postposition $=t u$ 'from' is affixed, are used to express and further delimit various spatial relations.

galla 'under' (from Ts gallo)

(94) inta hanca $=$ tu galla $k i=i ́ d a$

man tree-from under 3S.M-be_there.PST

'the man was under the tree'

ippa $=$ tu 'out of' ("door.from")

(95) janta wura $=t u \quad$ ippa=tu i=kát you house-from out 2S-go_out.PST

'you came out of the house'

gúskuto 'in, within' (gusku ? + =tu 'from')

(96) karbo wura=tu gúskuto ku=gáyya bird house-from within 3S.F-fly.PROG

'the bird is flying in the house' 
rúggitu 'above, over, upon' (ruggi ? + =tu 'from')

(97) karbo wura=tu rúggitu $k u=$ róota bird house-from over 3S.F-go.PROG

'the bird is flying over the house'

bagáttu 'behind' (baga ? + =tu 'from')

(98) inta wura $=k o=t u$ bágattu $k i=i d a \quad$ 'the man is behind the house' man house-DET-from behind 3S.M-be_there.PST

balYastu 'in front of' (balYas ? + =tu 'from')

(99) inta wura sinni=tu balYastu ki=dehéni

man house my-from front 3S.M-stop.PROG

'the man is sitting in front of my house'

(100) inta juuka=tu balYastu ki=yáwa

man girl-from front 3S.M-stand.PROG

'the man is standing in front of the girl'

3.6. Adjectives. There is not a unitary category "Adjective": many adjectival concepts are expressed by verbs, a minority of others by true adjectives.

3.6.1. Basic adjectives. A few adjectives have different endings for Masculine and Feminine, or for Singular and Plural, but most are invariable. A few native adjectives end in =uni, which is also used in derived adjectives from verbs (see below). A list of basic adjectives is given below.

(101) gaddaYuni; P: giddeYeta 'big; large; wide; fat, old (of people and animals)' munnuSuni; P: minfeta 'small, little; young (of people and animals)' $a b b a$

Sádala

Sádiba

'nice, beautiful; good; sweet'

'ugly; bad'

geccate; P: geccayke

'old' (for Masculine nouns only)

kamurko; F: kamurte

carba

'old' (for Feminine nouns only; from Ts)

hólbatuni

'rich' (from Ts)

'thin'

'short'

órma

'tall' (from Ts)

zaarakko; F: zaaratte;

P: zaarayke

mekente

'fool; crazy' (from Ts)

'sterile' (from Ts; subj: woman; for men the expression moolo tiibto ["the penis died"] is used 
3.6.2. Derived adjectives. A few adjectives are derived from verbs; an ending -ni has been noted in a few cases. Compare (102) with (103)-(104), (105) with (106), (107) with (108), and (109) with (110).

(102) inta=ko šaSatuni 'scared, fearful man' man-DET afraid

(103) kata ka=šaYatí 'I am afraid'

I 1S-be_afraid.NPST

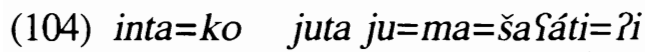
man-DET we 1P-NEG-be_afraid-NEG

(105) caßáw tsántuni 'cold water' water cold

(106) sibila=ko $k u=t s a ́ n$ iron-DET 3S.F-be_cold.PST

(107) $a y m a=k o$ erehte woman-DET pregnant

'we are not afraid of that man'

'the iron is (became) cold'

(108) $k u=e ́ r e h i$

3S.F-be_pregnant.PST

'she is pregnant'

(109) inta daafakko

'blind man'

man blind

'pregnant woman'

(110) kata ka=dáaf

I 1S-be_blind.PST

'I became blind'

3.6.3. Verbs with adjectival meaning. Other adjectival concepts are expressed through verbs.

(111) kata ka=malál I 1S.be_tired.NPST

'I am tired, weak' (from Ts)

(112) hanca ki=šóoni wood 3S.M-be_hot.PST

'the wood is (became) hot'

(113) caYa ku=bóYi stone 3S.F-be_hard.PST

'the stone is (became) hard'

(114) naYana $=k o \quad k u=t s a ́ q a m i$ food-DET 3S.F-be_salty.PST

'the food is (became) salty' 
3.6.4. Colors. Like other languages of the area (cf. Tosco [2001: 582ff.] for Dhaasanac), the color system of O has five basic colors:

$\begin{array}{ll}\text { áttomuni } & \text { 'white' } \\ \text { dákkamuni } & \text { 'black' } \\ \text { róomini } & \text { 'red' } \\ \text { cárkamuni } & \text { 'green' } \\ \text { silbe } & \text { 'yellow' }\end{array}$

The following non-basic colors have been recorded; note the use of silbe 'yellow' in these compounds.

silbe áttomuni

silbe cárkamuni

silbe dákkamuni

silbe róomini

moora

arrakko;

F: arratte; P: arrayke

$$
\begin{aligned}
& \text { 'light blue' ("yellow+white”) } \\
& \text { 'dark green' ("yellow+green") } \\
& \text { 'blue' ("yellow+black") } \\
& \text { 'pink; violet' ("yellow+red") } \\
& \text { 'light gray' (from Ts) } \\
& \text { 'dark gray' (from Ts) }
\end{aligned}
$$

3.6.5. Adjectival phrases. The adjective follows the noun it modifies. Both the noun and the adjective may be followed by a determiner.

(115) ayma=nki gaddaYuni=nki (sinni) 'the big woman (is my wife)' woman-DET big-DET my

(116) juuka=ko $a b b a=k o \quad(k a=h a ́ a b i n i)$ girl-DET nice-DET $1 \mathrm{~S}$-want.PROG

'(I want) a beautiful girl'

3.6.6. Comparatives and superlatives. In comparatives the adjective does not change; the subject may either precede or follow the element against which the comparison is made, which is followed by the postposition $=t u$ 'from'. The same construction, which is common in the area, is used in Ts.
a. inta $=n k i$ ayma $=k o$ áddate $=t u$ gaddaSuni
man-Det woman-Det there-from big
'the man is taller than that woman'

b. Ts:
qawko kutta gaant=issa kaysa=nu ko damma
man this woman-that there-to CONN big
'this man is taller than that woman' 
(118) a. ayma $=n k i=t u \quad$ inta $=n k i$ gaddaSuni woman-DET-from man-DET big 'the man is taller than the woman'

b. Ts:

gaante $=$ nu qawko damma

woman-to man big

'the man is taller than the woman'

(119) a. inta $=n k i$ inda $a y m a=k o \quad$ áddade $=t u a b b a$ man-DET this woman-DET there-from beautiful 'this man is more beautiful than the woman'

b. Ts:

qawko=kutta gaante kaysa=nu ko qayya man-this woman that-to CONN beautiful 'this man is more beautiful than the woman'

(120) a. ayma $=n k i=t u \quad$ inda áddate abba woman-DET-from this there beautiful 'that (woman) is more beautiful than this one'

b. Ts:

gešant=itta=nu kissa abba

woman-this-to that beautiful

'that (woman) is more beautiful than this one'

(121) a. hanca=nki baddi=tu inda gaddaSuni tree-DET all-from this big 'this tree is the biggest of all'

b. Ts:

gar=e xumbi=nu kutta ko damma tree-P all-to this CONN big 'this tree is the biggest of all'

Other sentences:

(122) $a y m a=n k i \quad$ inda=tu inta áddate gaddaSuni woman-DET this-from man there big 'that man is taller than this woman'

(123) wura siidi=tu wura sinni gaddaSuni house your-from house your big 'my house is bigger than yours' 
For the equative comparative, the Ts structure with the Ts word gura 'like' following the second element is used.
a. hanca=nki hanca=nki áddate gura gadda@uni tree-DET tree-DET there like big 'this tree is as big as that one'
b. Ts:
garko kutta garko kaysa gura ko damma tree this tree there like CONN.M big 'this tree is as big as that one'

Sometimes $=t u$ appears also after the second element in an equative comparison.

(125) inta $=n k i$ ayma $=k o \quad$ addate $=t u$ gura $a b b a$

man-DET woman-DET there-from like beautiful

'this man is as beautiful as that woman'

\subsection{Numerals}

3.7.1. Cardinals. The following numerals have been recorded:

$\begin{array}{ll}\text { kálbano akkálbano } & \text { 'one'9 } \\ \text { lama } & \text { 'two' (Cushitic) } \\ \text { zaha } & \text { 'three' (Ts zéh) } \\ \text { tálaha } & \text { 'four' (Ts tálaha) } \\ \text { xubbi } & \text { 'five' (Ts xobín) } \\ \text { tsanafa } & \text { 'six' } \\ \text { tahanke } & \text { 'seven' (Ts tahán) } \\ \text { ista } & \text { 'eight' } \\ \text { gollanke } & \text { 'nine' (Ts gollán) } \\ \text { coma } & \text { 'ten'10 }\end{array}$

9 The form akala mentioned by Fleming et al. [1992/93: 203] has not been found. On the other hand, kálbano akkálbano apparently contains a formative -bano which is also found in the special forms for 'two' and 'three' used in numeral phrases (see 3.7.2).

10 When counting or mentioning numbers, the oral expression of the numbers is usually accompanied by a conventional manipulation of the fingers; the numbers up to ten are expressed as follows:

1: little finger curled by the other hand, other fingers extended;

2: little finger and ring finger curled by the other hand, other fingers extended;

3: little finger, ring finger and middle finger curled by the other hand, other fingers extended;

4: all fingers except the thumb curled by the other hand, thumb extended;

5: all fingers clenched over the thumb;

6: thumb of left hand held between the thumb and the forefinger of right hand; other fingers of left hand extended; 
Teens are formed with coma 'ten' followed by the unit, for example:

coma akkálbano 'eleven'

dibba ([ dippa $]$ 'hundred'

(cf. Dullay dippá [Amborn, Minker \& Sasse 1980: 96])

3.7.2. Numeral phrases. The numeral always follows the head noun. The following special forms used in phrases have been recorded (see also fn. 9).
lámbano 'two'
zéhbano 'three'

(126) $w u r a=k o$ áddate zéhbano $k u$ sinni 'those three houses are mine' house-DET that three 3S.F my

The other numerals are used in phrases without changes.

(127) $w u r a=k o$ áddate $x u b b i$ ku sinni 'those five houses are mine' house-DET that five 3 S.F my

3.8. Adverbs. A few elements have been tentatively classified as adverbs; they can precede or follow a noun or an emphatic subject pronoun, but always precede the verb and the pronominal clitics.

Adverbs of time:

barám barama 'tomorrow':

(128) barama kata ka=kolí

tomorrow I 1S-return.NPST

'I will return tomorrow'

7: thumb and forefinger of right hand inserted between the thumb and the forefinger of the left hand; the forefinger of the left hand is curled, while the other fingers are extended;

8: thumb, forefinger and middle finger of the right hand inserted between the thumb and the forefinger of the left hand; the fingers of the left hand are extended;

9: all fingers of the right hand except the little finger inserted between the thumb and the forefinger of the left hand; the fingers of the left hand are extended;

10: both hands as for 5.; the two fists knocked together.

This system is, in a way, the reverse of the one used among the Dhaasanac [cf. Tosco 2001: 108]; in particular, the Dhaasanac start from the forefinger and proceed toward the little finger, while the Ongota start from the little finger; among the Dhaasanac, extension of one or more fingers expresses the counted number, while the other fingers are kept curled, while for the Ongota it is the curling of one or more fingers which expresses the counted number. For example, among the Dhaasanac 1 . is expressed extending the forefinger and keeping the other fingers curled; for 2. the forefinger and the middle finger are extended, and so on. 
naxani 'yesterday':

(129) kata naxani $k a=g a ́ S i \quad$ 'yesterday I ran'
I yesterday $1 S$-run.PST

burinki 'this morning':

(130) burinki ka=málal baram ka=dangád

this_morning 1S-be_tired.PST tomorrow 1S.work.NPST

'this morning I was tired, I will work tomorrow'

wuuni 'today':

(131)
wuuni ka=róo
today $1 \mathrm{~S}$-go.PST
'I went today'

ayke 'now':

(132)

ayke ka=róota 'I am going now'

now 1S-go.PROG

qarra 'before':

(133) qarra $k u=b o ́\{i=b a$

ayke cárqamuni

before 3S.F-be_fresh.PST-and now green

'before it was fresh and now is yellow'

sidda 'before':

(134) juuka=ko sidda abba ayke Gádala

girl-DET before nice now ugly

'the girl before was nice, now she is ugly'

kolba 'again' has been found only in the sentence:

(135) ayma ka=išéeni=ba kolba ka=háabini

woman 1S-bring.PROG-and again 1S-want.PROG

'I have a woman and I want another one'

Adverbs of quantity and intensity

ekkete 'much':

(136) ekkete caká 'eat a lot!'

much eat.IMPV.S

(137) ekkete riirá 'scream loudly'

much scream.IMPV.S 
iccama 'a little bit; slowly':
(138)
iccama caká
'eat a little!'
little eat.IMPV.S
(139) iccama rootá
little go.IMPV.S
'go slowly!'

The adjective abba 'good' is used as an adverb with the meaning 'well, properly':

(140) kita cata abba ki=gádi

he meat good 3S.M-cut.PROG

'he is cutting the meat properly'

The following adverbial phrases have been noted:

qane qane 'sometimes' and qane badde 'always' (Lit. "all day". A calque of Ts qane xumbi. Cfr. Amh $k$ 'sn 'day').

(141) qane badde kara ka=cákini

'I am always eating fish'

day all fish $1 \mathrm{~S}$-eat.PROG

kanna kanna 'quickly' (Ts kanna kanna):

(142) kanna kanna ki=róota quickly 3S.M-go.PROG

'he is going quickly'

3.9. Verbs. The following categories find expression in verbal inflection:

— tense: Past (: PST), Non-Past (: NPST);

- aspect: unmarked vs. Progressive (: PROG);

- mood: Main, Imperative (: IMPV), Jussive, Verbal Noun or Infinitive (: INF);

- polarity: Positive vs. Negative (the latter tagged NEG).

It will be noted that the person, number, and gender of the subject of the sentence is not indexed on the verb itself, although a few verbs use different stems for Singular and Plural Subjects and/or Objects. Other categories find their expression in verbal derivation; the simplest form of a stem, both morphologically and semantically, is the Basic stem. From a Basic stem one or more derived stems are derived through suffixation.

Inflection may be suffixal or suprasegmental (tonal); derivation is exclusively suffixal. 11

11 It is difficult to decide whether the extreme reduction in inflectional categories expressed on the verb is exclusively a function of the obsolescence of the language; other Cushitic languages, all of them spoken in close contact with non-Cushitic languages, show similar, although perhaps not so radical, reduction: Dhaasanac, Elmolo, and Yaaku are the most evident examples. But two 
3.9.1. Basic stems. In the following discussion and in the Lexicon, verbs will be given under their stem forms, which never surface as such; for most verbs the stem is actually identical to the form found in the Past and Non-Past, but without accent (cf. 3.9.3); this is also the form to which suffixes (both derivational and inflectional) are added. This applies to the consonant-ending verbs, which are the vast majority of all verbs. Among the consonant-ending verbs, most are monosyllabic and have the shape $\mathrm{CV}(\mathrm{V}) \mathrm{C}$; a minority are bi- and pluri-syllabic.

A good number of verbs are vowel-ending; the final vowel is $-i$ in the tensed forms, but -e before the inflectional suffixes. Finally, no final vowel is generally found before the derivational suffixes. For example, one finds the following forms:
Past:
$k a=m u ́ x i$
'I laughed'
Non-Past:
$k a=$ muxí
'I laugh, will laugh'

but

Imperative Singular: muxé 'laugh!'

Imperative Plural: muxéta 'laugh! (P) and

Causative, Past: $\quad k a=$ múxsan $\quad$ 'I made laugh'

Considering that only /e/ or $\emptyset$ are found before suffixes, and taking into account Final Height Neutralization (cf. 2.3.1), it is possible to consider these verbs as ending in -e in their stem-form. As shown above, both /i/ and /e/ appear wordfinally; now, while it is tempting to hypothesize that a final accented /e/ avoids raising, thereby accounting for, for example, the Past $k a=m u ́ x i$ 'I laughed' vs. the Imperative Singular muxé 'laugh!', this would leave unexplained the Non-Past $k a=$ muxí 'I laugh, will laugh'. It is tentatively assumed here that /e/is the final stem-vowel and that raising to $/ \mathrm{i}$ is morphologically determined; all the basic vowel-ending verbs are therefore reported with a final /e/ in the following discussion and in the Lexicon. A few examples are: aame-'to rest', ame-'to suck', ee-'to come', išee-'to bring', Yebe $e$-'to vomit', ba Sce-'to carry on the back', be?e-'to give', berre-'to touch', boye-'to cry', goxe-'to put out', mayye-'to kiss', muxe-'to laugh'

3.9.1.1. Plural stems. A few verbs have different stems for Singular and Plural Subject and/or Object. These verbs are the following:

of these (Elmolo and Yaaku) were recorded in their terminal stages, too. Derivation has been on the whole more resistant to decay than inflection. 
Singular stem Plural stem

\begin{tabular}{|c|c|c|c|}
\hline gay- & bagat- & 'to run' & Cfr. Ts sor $(\mathrm{S}), \operatorname{bagad}(\mathrm{P})$ \\
\hline xo?- & kuše- & 'to hit', & \\
\hline $\begin{array}{l}\text { gad- } \\
?\end{array}$ & qits- & 'to cut' & Cfr. Ts qits \\
\hline $\begin{array}{l}? \\
\text { dehe- }\end{array}$ & $\begin{array}{l}\text { xot- } \\
\text { aame- }\end{array}$ & $\begin{array}{l}\text { 'to put down' } \\
\text { 'to stop (intr.)' }\end{array}$ & \\
\hline at- & & 'to make fall' & \\
\hline kat- & foof- & 'to leave' & \\
\hline reex- & $?$ & 'to go down' & \\
\hline
\end{tabular}

(143) kita hanca kí=gad he tree 3S.M-cut.NPST

'he'll cut the tree'

(144) ki?ita hanca ki?a $=q i t s$

they tree 3P-cut.P.NPST

'they'll cut the tree'

Other verbs seem to be used only with plural subjects, without a corresponding singular stem.
$\begin{array}{lll}\text { - } & \text { hadi- } & \text { 'to collect, pick up' } \\ \text { - } & \text { hokam- } & \text { 'to exchange' }\end{array}$

3.9.2. Derived stems. The productive derivational system consists of a Causative (CAUS) extension and of a Reflexive-Middle (MID) extension (whose productivity is unclear).

3.9.2.1. Causative. The most common extension is -san; possibly this was, at least originally, a compound Causative-Passive extension, since a scarcely productive extension -am is found with an Intransitive meaning (cf. 3.9.2.3).

The Causative in -san is completely productive. Basic vowel-ending verbs (cf. 3.9.1) delete their final -e before the extension.

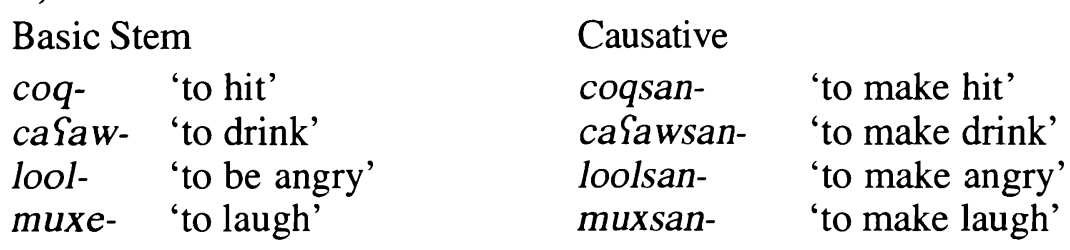

A second Causative derivation, apparently of less productivity, is $=i s$. This is the same suffix used in Ts, and is frequent with Ts loans, but not limited to them.

Basic Stem

bagat- 'to run' (P subj.)

gutal- 'to jump, dance, sing'

goh- 'to grow' (from Ts)

kox- 'to leak'
Causative

bagtis-

gutalis-

gohis-

koxis- 'to make run' (P subj.)

'to make jump, dance, sing'

'to make grow'

'to make leak' 
In a few cases, both -san and -is have been recorded, with apparently no difference in meaning:

Basic Stem

mag- 'to take another road'

morom- 'to speak'

sal- 'to wait' (from Ts)

tiid'to put, store' -is Causative -san Causative

magis- magsan- 'to cause to take.. moromis $=$ moromsan- 'to make speak'

salis- salsan- 'to make wait'

tiid-is-/-as- tiidsan- 'to make put'

A few verbs have, possibly as a variant of -is, a Causative extension -as (or -aš, very possibly a variant of -as):

Basic Stem

ucce- ' to pour, fill' (from Ts)

Sad- 'to lick'

diig- 'to pour' (from Ts)
Causative

uccaš- 'to make pour'

Sadas- 'to make lick'

diigas- 'to make pour'

Finally, the following shows a Causative -os, apparently borrowed from a Dullay variety other than Ts together with the Basic stem:

Basic Stem

daggab- 'to arrive'
Causative

daggabos- 'to make arrive'

3.9.2.2. Middle. The usual Cushitic Reflexive-Middle (or Auto-benefactive) extension is found in $\mathrm{O}$ with the unusual shape $-i$, which has been recorded for a substantial number of verbs.

Basic Stem

boš- 'to pick up, collect'

coq- 'to spear, sting'

gad- 'to cut'

ges- 'to shave'

hobat- 'to wash'
Middle

boši?- $\quad$ 'to pick up for o.s.'

coqi?- 'to spear for o.s.'

gadi?- 'to cut for o.s.'

gesi?- 'to shave o.s.'

hobati?- 'to wash o.s.'

In fili?-'to comb', the Middle extension has been added to a loan verb (Ts fil) without a Basic correspondent. Other verbs, such as goi?-'to take, get' and Siqqiši?- 'to sneeze', are found only in their Middle forms without a Basic stem.

3.9.2.3. Intransitive. An Intransitive extension in -am has been recorded for a few verbs. It is evidently connected to the Passive East Cushitic extension of the same form, and, as anticipated, could be the origin of the common Causative extension -san. 
Basic Stem

bul- 'to pull out'

lax- 'to mix' (tr.)

šud- 'to cover, dress' (Ts)

xot- 'to put down'
Intransitive

bulam- 'to be pulled out'

laxam- 'to mix' (intr.)

šudam- 'to wear'

xotam- 'to go down'

At least the following has an irregular double Intransitive extension -mam.

Basic Stem

caq- 'to hide'
Intransitive

caqmam- 'to hide oneself'

A few Intransitive-extended verbs have been recorded without a corresponding Basic stem, such as Pifam-'to marry', hokam-'to exchange (P. subj.; from Ts). Maybe also morom-'to speak' belongs here.

The opposition between a Basic transitive stem and its Intransitive derivate may be seen in the following sentences:

(145) kuta eefi=na caYáw ella=ki ku=láx

she milk-and water together-to 3S.F-mix.PST

'she mixed the milk with water'

(146)

eefi=na caYáw ella =ki ku=láxam

milk-and water together-to 3S.F-mix.INTR.PST

'the milk mixed with water'

The complete series of (regular) derivational possibilities is illustrated, for example, in the following:

Basic Stem

bul- 'to pull out'

diig- 'to pour into' (from Ts)
Middle

buli?-

diigi?-
Intransitive

bulam-

diigam-
Causative bulsandiigas-

3.9.2.4. Frozen derivational extensions? A few verbs appear with a dental ending in their Basic stem; while for a few of them a Ts origin is evident, this is not always the case. They can act as the base of further, "true" derivation:

\author{
Basic Stem \\ Sangat- 'to mix' (tr.) \\ hobat- 'to wash' \\ nabad- 'to hate' (from Ts) \\ noqot- 'to look, aim at' (from Ts)
}

3.9.3. Tense. A twofold opposition Past vs. Non-Past is found. The Non-Past is used for an incomplete action, either present or future. The Past tense is marked by tone on the first (or only) mora of the verbal form. If the verb stem is a long monosyllabic one (CVVC), the sequence High-Low yields a falling tone. The Non- 
Past tense is marked by absence of tone on the mora of the stem if this is monomoraic (CVC). In this case, the Subject Clitic gets High tone; a certain amount of non-phonological lengthening of the stem vowel is occasionally heard.

(147)
$\begin{array}{ll}\text { a. (kata) } & k a=b u ́ d \\ \text { I } & 1 S \text {-spit.PST }\end{array}$
'(me,) I spat'
$\begin{array}{cll}\text { b. (kata) ká=bud [burd] } & \text { I } 1 S \text {-spit.NPST }\end{array}$
'(me,) I'll spit'

(148)
a. $k a=c i ́ g$
'I sewed'
1S-sew.PST

b. $k a ́=c i g$

1S-sew.NPST

(149)
a. $k a=c o ́ q$
'I hit'
1S-hit.PST

b. $k a ́=c o q$

'I'll hit'

1S-hit.NPST

(150)
a. tampo $k a=s u ́ g$
tobacco $1 \mathrm{~S}$-sniff.PST
'I sniffed tobacco'

b. tampo ká=sug

tobacco $1 S$-sniff.NPST

(151)
a. ka=héd
'I tied'
1S-tie.PST
b. ká=hed
'I'll tie'
1S-tie.NPST

'I'll sniff tobacco'

If the verb is at least bimoraic, the verbal form gets a Tone on the last mora and the Subject Clitic does not get High tone. If the stem is a long monosyllabic one (CVVC), the sequence Low-High yields a rising tone.
a. $k a=x a ́ a b$ [xáàb] 'I scratched'
1S-scratch.PST

b. $k a=x a a ́ b$ [xàáb] 'I'll scratch'
1S-scratch.NPST

(153)
a. $k a=z i i$ ?
'I farted'
1S-fart.PST
b. $k a=z i$ ?
1S-fart.NPST
'I'll fart' 
If the stem is bi- or pluri-syllabic the Non-Past has High tone on the last mora.
a. naxani ju=iški 'we played yesterday' yesterday 1P-play.PST
b. barám ju=iškí 'we'll play tomorrow' tomorrow 1P-play.NPST

(155)
a. kata $k a=$ I $i k k i s ̌ i$
I $1 S$-sneeze.PST
'I sneezed'
b. kata $k a=$ Sikkiši
I $1 \mathrm{~S}$-sneeze.NPST
'I'll sneeze'

Native verbs and loans do not differ in their treatment, as shown by the following verbs from Ts.
(156)

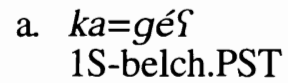
'I belched'
b. ká=geS
1S-belch.NPST
'I'll belch'
(157)
a. $k a=g u ́ f a S$
1S-cough.PST
'I coughed'
b. $k a=g u f a ́ s$
1S-cough.NPST
'I'll cough'

3.9.4. Aspect. An on-going action is expressed through the Progressive ending -i/ni. The verb receives the accent on the first vowel. Verb stems ending in a consonant (cf. 3.9.1) add $-i$; verbs ending in a vowel add -ni. Compare the following sentences.
a. barám kata ka=dangád tomorrow I $1 \mathrm{~S}$-work.NPST
'tomorrow I'll work'
b. inta gúlbata $=m i$ ki=dángadi man strength-with 3S.M-work.PROG
'the man is working hard'

(159) a. naxani narfe $=m e \quad k a=c i ́ g$ yesterday needle-with $1 \mathrm{~S}$-sew.PST 'yesterday I sewed with the needle'

b. barám narfe=me ká=cig tomorrow needle-with 1S-sew.NPST

'I'll sew with the needle tomorrow'

c. ayki narfe=me $k a=c i ́ g i$

'I am sewing with the needle now' now needle-with $1 S$-sew.PROG 
(160) a. naxani kata kara ka=qáfi yesterday I fish 1S-catch.PST

'yesterday I fished'

b. barám kata kara ka=qafí tomorrow I fish 1S-catch.NPST

'I'll fish tomorrow'

c. ayki kara $k a=q a ́ f i n i$

now fish 1S-catch.PROG

(161) a. naxani kata ka=hóbi yesterday I 1S-wash.PST

'I am fishing now'

b. barám kata ka=hobí tomorrow I 1S-wash.NPST

'yesterday I washed'

c. kata ka=hóbini

I 1S-wash.PROG

'I'll wash tomorrow'

'I am washing'

(162)
a. naxani na $i[n e]=x a ́$ yesterday what $2 \mathrm{~S}$ do.PST
'what did you do yesterday?'
b. barám na i=xa [= néxa] tomorrow what $2 \mathrm{~S}$-do.NPST
'what will you do tomorrow?'
c. ayki na $i[$ ne]= xáni now what $2 \mathrm{~S}$ do.PROG
'what are you doing now?'

The verb roo-'to go' has an irregular Progressive in -ta.

(163) caßáw=ki ka=róota

'I am going to the river'

river-to $1 \mathrm{~S}$-go.PROG

The Progressive may be used for an on-going action in the present or in the past.

(164) caイáw=to ka=éeni river-from $1 S$-come.PROG

'I am coming from the river'

(165) naxani $k a=a ́ x a y=b a \quad k a=q a ́ f i n i=b a \quad k u=g i ́ r i b$ yesterday 1S-get_up.PST-and 1S-catch.PROG-and 3S.F-be_night.PST 'yesterday I woke up and spent the day fishing until it became night'

(166) kita ki=éeni na=tu kata ka=yób he 3S.M-come.PROG what-from I 1S-see.PST 'I saw him as he was coming from over there'

(167) kita ki=éeni na=tu juta ju=yób he 3S.M-come.PROG what-from we 1P-see.PST 'we saw him as he was coming from over there' 
(168) caYáw=ki ki=róota na=tu kata ka=yób

water-to 3S.M-go.PROG him-from I 1S-see.PST

'I saw him as he was going (there) to the river'

3.9.5. Negative paradigms. For both the Past and the Non-Past a single Negative form is used, marked on the verb by a suffix $-? i$ and by a negative marker ma (both glossed NEG) preceding the verbal form.

(169) barama kata $k a=m a=e ́ e n i-? i$ tomorrow I $1 \mathrm{~S}-\mathrm{NEG}$-come.PROG-NEG

(170) kata $k u=m i \quad k a=m a=m o ́ r o m i-P i \quad$ 'I don't speak with her' I $\quad 3$ S.F-with 1S-NEG-speak-NEG

3.9.6. Imperative. The Positive Imperative (: IMPV) Singular of consonant-ending verbs (cf. 3.9.1) is marked by final High-toned -á; the Plural by 'ta.
(171) budá 'spit!'
spit.IMPV.S
búdta
spit.IMPV.P
(172) gufạá 'cough!' cough.IMPV.S
gufásta 'cough! (P)' cough.IMPV.P

Vowel-ending stems (cf. 3.9.1) end in their Imperative Singular in High-toned -é, while for the Plural the same -ta ending of all other verbs is used.
(173) muxé
laugh.IMPV.S
muxéta 'laugh (P)!'
laugh.IMPV.P

3.9.6.1. Irregular imperatives. The Imperative of roo- 'to go' is built from the irregular Progressive (cf. 3.8.3) róota: S rootá, $\mathrm{P}$ róotta. The verb xa?- 'to do' extends its stem in the Imperative: $\mathrm{S}$ xaašá, $\mathrm{P}$ xáašta. As in many Ethiopian languages, the verb ee-'to come' has a suppletive Imperative: S háy, P háyta.

3.9.6.2. Negative imperative. The Negative Imperative uses the special Negative element intima (composed with ma?).

(174) intima qáfi 'don't fish!' intima gida qáfi 'don’t (P) fish!'
NEG fish

3.9.7. Jussive. A separate Jussive form has been found for the 1st Plural only and is built with the suffix -itu (after consonant) or -tu (after vowel; but a few irregular forms have been found). 


\begin{tabular}{|c|c|c|c|c|}
\hline \multirow{13}{*}{ (175) } & axay- & axáytu & 'let's stand up!' & \multirow{13}{*}{$\begin{array}{l}\text { (note the idiom cáxma jî?tu } \\
\text { 'let's eat!' ["let's kill meat!'] }\end{array}$} \\
\hline & boye- & bóytu & 'let's cry!' & \\
\hline & caৎaw- & caßawítu & 'let's drink' & \\
\hline & jiP- & jî?tu & 'let's kill!' & \\
\hline & fa? - & faYítu & 'let's kindle!' & \\
\hline & gad- & gadítu & 'let's cut!' & \\
\hline & muxe- & muxítu & 'let's laugh!' & \\
\hline & roo- & róoytu & 'let's go!' & \\
\hline & tagam- & tagamítu & 'let's sleep!' & \\
\hline & tiid- & tiidítu & 'let's put!' & \\
\hline & tsug- & tsug'itu & 'let's lie down!' & \\
\hline & yaw- & yawítu & 'let's stop!' & \\
\hline & yawsan- & yawsanitu & 'let's make stop!' & \\
\hline
\end{tabular}

3.9.8. Infinitive. Verbs in the basic stem, both monosyllabic and bisyllabic, make their Infinitive with the suffix $-C o$ (where $C$ is the last stem consonant); the accent falls on the first syllable. The Infinitive is used in object and subject clauses (cf. 4.8).

(176) kata kara šúbbo ka=háabini 'I want to kill fish'

I fish kill.INF 1S-want.PROG

(177) rotto ka=háabini go.INF 1S-want.PROG

(178) jami xó??o ka=háabini you.OBJ hit.INF 1S-want.PROG

(179) ca\{áw bá?co ka=háabini water carry.INF 1S-want.PROG

(180) laalbe šúdammo ka=háabini 'I want to put on the dress' dress wear.INF $1 S$-want.PROG

(181) oxoni gúyyo ka=háabini fire kindle.INF 1S-want.PROG

'I want to go'

'I want to hit you'

'I want to carry water (on the back)'

(182) kata tágammo ka=háabini I sleep.INF $1 S$-want.PROG

'I want to kindle the fire'

(183) kuta šu?una šúgucco ku=háabini
she butter smear.INF 3S.F-want.PROG 'she wants to smear butter' 'I want to sleep' 
(184) kata Yikkišaddo ka=háabini

'I want to sneeze'

I sneeze.INF $1 S$-want.PROG

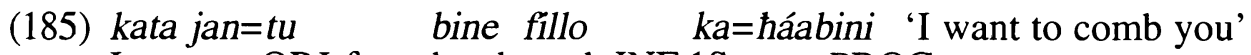
I you.OBJ-from head comb.INF 1S-want.PROG

(186) inta wora=ki gíšso ki=háabini man house-to enter.INF 3S.M-stop.PROG the house'

Vowel-ending stems have a suffix -le; again, the accent falls on the first syllable.

(187) bóyele ka=háabini

'I want to cry'

cry.INF 1S-want.PROG

(188) qáadile ka=háabini 'I want to lie down' lie_down.INF 1S-want.PROG

(189) šóxele $\quad k a=h a ́ a b i n i \quad$ 'I want to have sex'

have_sex.INF 1S-want.PROG

(190) gidata kúšile ka=háabini 'I want to hit you (P)' you.P.OBJ hit.INF $1 S$-want.PROG

3.9.9. 'to have'. "to have" is expressed by the construction "from me $X$ is", widely found in Ethiopian languages. It has a parallel also in Ts.
a. $k a=t u \quad$ darbo $k u=i d a$
'I have a skin' me-from skin 3S.F-there_is

b. Ts:

eeta doolte Sagay

to-me skin there_is

(192) a. gida=tu darbo ku=ida 'you (P) have a skin' you(P)-from skin 3S.F-there_is

b. Ts:

ineta doollo Sagay

to-you $(\mathrm{P})$ skin there_is

The negative form employs the negative of ba 'to be', which is a borrowing from Ts.
a. $k a=t u \quad b a$
'I do not have'
me-from not_be
b. Ts:
eta ba
to-me not_be 

bring'.

'to have' is also expressed through the Progressive form of the verb išee- 'to

(194) kata ayma ka=išeeni

I woman 1S-bring.PROG

(195) kita hugu ki=išeeni

he itching 3S.M-bring.PROG

(196) kata bor=mi jata ka=išeeni

I stomach-with you 1S-bring.PROG

(197) inta iifa $k i=m a=i s ̌ e e n i$

man mouth 3S.M-NEG-bring.PROG
'I have a woman'

'he is itching'

'I remember you'

("I bring you in the stomach")

'a man who has no mouth'

(i.e. a dumb man)

\section{Syntax}

$\mathrm{O}$ is an SOV, dependent-marking language. The verb is the last element of a sentence, but a pronominal object often follows the verbal form (v. 4.3.2).

4.1. Noun Phrases. The Noun is the first element of the phrase; a Possessive immediately follows the head, but the relative order of other modifiers is apparently free.

(198) wura sinni lama

'my two houses'

house my two

(199) wura sinni lama gidde Yeta 'my two big houses'

house my two big.P

but:

(200) wura sinni minfeta lama 'my two little houses'

house my little.P two

(201) ayma $=k o \quad$ maar $k u=m a=x o ́ d i(=? i)$

woman-DET child 3S.F-NEG-generate.PST(-NEG)

'a woman who did not gave birth to a child'

4.2. Genitival phrases. The Possessed precedes the Possessor; in closed, possibly frozen, expressions, no element intervenes.

(202) iifa Songota 'the Ongota language ["mouth"]' mouth $\mathrm{O}$.

Generally, the Possessor is further followed by an element $=t e$ :

(203) ii?a inta=te 'the man's hand' hand man-? 
(204) cawo inta $=$ te

'the man's gun'

gun man-?

(205) wura inta $=$ te/ayma $=$ te/yooba $=t e$ 'the man's, woman's, people's house' house man-?, woman-?, people-?

(206) ippa wura=te 'the door of the house'

door house-?

The possessed may be followed by se, glossed 'of', which is also found in the Possessive pronominal elements. Its use is sporadic; it could also result from the transfer into $\mathrm{O}$ of the common Ts Determinative or connector -se.

(207) iipa se inta=te 'the man's hand'

hand of man-?

Frequently the first element is followed by the Determiners $=k o$ or $=n k i$.

(208) iipa se inta=nki=te 'the man's hand'

hand of man-DET-?

A reverse Possessor-Possessed is possible but, apparently, less used. In this case, the Possessor precedes, followed by the eventual Determiners and the case-marker $=t u$ 'from'; the Possessed is, in its turn, followed by the Possessive pronominal referring to the Possessor following the possessed.

(209) inta=nki tu ii?a seena man-DET from hand his

(210) ayma=nki tu ii?a suu?u woman-DET from hand her 'the man's hand'

("from the man, his hand")

'the woman's hand'

("from the woman, her hand")

This order is instead normal when further modifiers are present.

(211) wura sinni tu ippa house my from door

(212) wura ayma=ko tu ippa house woman-DET from door 'the door of my house'

("from my house, the door")

'the door of the woman's house'

("from the woman's house, the door")

4.3. Sentences. Although verbs are the prototypical predicates, also nouns, adjectives, possessives, and numerals may act as predicates in nominal sentences (see 4.6).

4.3.1. Subjects. A nominal subject is normally found in sentence-initial position; there are reasons to believe that such nouns do not act as the syntactic subjects of the sentence, a function which is rather filled by a Subject Clitic; only the presence of a Subject Clitic is mandatory for any declarative clause, while a noun may 
appear in the first position in the clause or also (possibly as a right-dislocated topic?) at the end, or may be altogether absent.

4.3.2. Objects. The only element that can intervene between the Subject Clitic and the Verb is the Negative marker ma. An Object Pronoun can take the position of a corresponding object noun before the Subject Clitic.

(213) kata uke $k a=j i 1 ?$
I elephant $1 S$-shoot.PST

and:

(214) kata ki ka=jii $\quad$ 'I shot him'

I $3 S . M 1 S$-shoot.PST

Sentence (214) above may be analyzed as having the structure:

$$
\begin{aligned}
& {\left[{ }^{[k a t a}\right]_{\text {Top }}\left[[\mathrm{uke}]_{O}\left[[\mathrm{ka}]_{S}[\mathrm{ji} P]_{\mathrm{V}}\right]_{\mathrm{VC}}\right]_{S}} \\
& \text { I elephant } 1 \mathrm{~S} \text { shoot.PST }
\end{aligned}
$$

More commonly, an Object Pronoun is affixed after the verbal form. It can also be introduced with an Emphatic Pronoun or repeated after the verb.

(215) kita cata ki=gás

'he bit the meat'

he meat 3S.M-bite.PST

vs.

(216) gabare $k i=g a ́ s=k i \quad$ 'a snake bit him' snake 3S.M-bite.PST-him

An indirect object precedes the direct object.

(217) šiggi=tu maara xódi
us-to boy generate.PST

4.3.3. Passive (Impersonal construction). A passive construction is expressed through the use of the Impersonal Subject Pronoun a (ISP); the object follows the verbal form:

(218) (kata) a=xódi=ka

I ISP-generate.PST-me

'I was born' ("me, they generated me”)

(219) (janta) a=xódi=jámi

'you (S) were born'

you ISP-generate.PST-you

(220) (kita) $a=x o ́ d i=k i$

'he was born'

he ISP-generate.PST-him 
(221) (kuta) a=xódi=ku

'she was born'

she ISP-generate.PST-her

(222) (juta) $a=x o ́ d i=j u$

'we were born'

we ISP-generate.PST-us

(223) (gidata) a=xódi=gita you ISP-generate.PST-you.OBJ

(224) (ki?ita) a=xódi=ki?i

they ISP-generate.PST-them

'you $(\mathrm{P})$ were born'

'they were born'

The Negative Paradigm involves the (optional?) use of the Negative particle ma (NEG), which is often missing, and, obligatorily, of the suffix $=? i$ at the end of the verbal form:

(225) (kata) a=(ma) xódi=ka=?i 'I was not born'

I ISP-(NEG) generate.PST-me-NEG

(226) (janta) a=(ma) xódi=jámi=?i 'you (S) were not born' you ISP-(NEG) generate.PST-you-NEG

4.3.4. Reciprocal and Reflexive. Both a Reciprocal and a Reflexive are expressed through the use of ella or elella 'self' and 'together' (from Ts) and the clitic =na 'and' after the first element:

(227) $k a=n a$ jami ju=šúb ella 'we (me and you) killed each other' 1S-and 2S 1P-kill.PST self

$\begin{array}{ll}\text { (228) } k i=j i ̂ & \text { ella } \\ \text { 3S M-killPST self }\end{array}$ 'he killed himself'

(229) $k a=g a ́ d \quad$ ella

'I cut myself'

1S-cut.PST self

(230) juta elella ju=éeni we together 1P-come.PROG

'we come together'

Followed by a postposition:

(231) caYáw=na eefi ella=ki reekisá 'mix milk with water!' water-and milk self-in mix.IMPV.S

\subsection{Questions}

4.4.1. Content questions. Content questions ("Wh-questions") do not have fronting of the question word. When the question word is subject of the sentence, no Subject Clitic is found, a fact that can be assumed to imply that the question word is always focalized. 
haka 'who?':

(232) haka ée who come.PST

$$
\text { 'who came?' }
$$

Note the following idiom:

(233) $m e \check{a} a=k o$ siidu haka

'what's your name?' name-DET your.S who

sae 'whose?':

(234) wura=nki sae 'whose is the house?' house-DET whose

A possible elliptical answer is:

(235) se ayma=te 'It is the woman's' of woman-of

na 'what?':

(236) na $k i=x a ́$ what 3S.M-happen.PST

'what did he do?'

haw = 'where?':

The element haw $=$ 'where' is always followed by a postposition:

(237) haw=ki i=áskam where-to 2S-go.PST

(238) haw $=$ tu $\quad i=e ́ e n i$ where-from 2S-come.PROG

bari 'when?':

(239) bari i=ée when $2 \mathrm{~S}$-come.PST

ayta 'which?':

(240) cawo ayta $i=h e ́ e n i$ gun which 2 S-like.PROG 'where did you go?'

'where are you coming from?' 'when did you come?'

'which gun do you like?'

mila 'how much/many?':

(241) kara mi?a $\quad i=j i ?$ fish how-many $2 \mathrm{~S}$-catch.PST 'how many fish did you catch?' 
$n a=k u$ 'why?' ("what-for"):

(242) na=ku i=éeni

what-for 2S-come.PROG

'why are you coming?'

ašana 'how?':

(243) ašana ki=đángat

'how did he do it?'

how 3S.M-do.PST

4.4.2. Polar questions. Polar questions are marked by a final $=\Re 1$ (INT) on the verb and by a rising intonational contour.

(244) janta naxani kara $i=q a ́ f i=? i$

you yesterday fish $2 S$-fish.PST-INT

'did you go fishing yesterday?'

When the question relates to the subject of the sentence, no Subject Clitic is present on the verb; as in the case of content question words (cf. 4.4.1), it can be assumed that this is because a questioned nominal is inherently focused.

(245) mole=mu aburre ée

M.-or A. come.PST

'was it Mole or Aburre who came?'

\subsubsection{Greetings}

(246) a. ášana $i=t a g$

how 2S-sleep.PST

'how did you sleep?'

b. janta nágayko tág=í

you peace sleep.PST-INT

'did you sleep in peace?'

answer:

(247) abba ka=tág

good 1S-sleep.PST

'I slept well'

or simply nágayko 'peace' (from Ts).

4.5. Direct speech. The quoted speech follows the main clause.

(248) kita $k u=$ tu $k i=g i ́ s i=n a \quad$ caSáw laxá

he her-to 3S.M-tell.PROG-and water mix.IMPV.S

'he told her: "mix the water!"'

4.6. Nominal sentences. In nominal sentences no verb appears and the role of predicate is fulfilled by an adjective or a noun, introduced by a Subject Clitic. Absence of the latter is found in focalized nominal sentences (see 4.11), in which 
the subject noun (or an Emphatic pronoun) is followed directly by the nominal predicate.

(249) kata munnuSuni 'I am small'

I small

In negative nominal sentences the usual negative markers ma and $=? i$ (affixed to the noun or adjective in predicative position) appear. Pi and ma can also both follow the predicate.

(250)
a. kata gadda\{uni $\$ i=m a$
I big
NEG-NEG
'I am not big'
b. kata ma gadda $\{u n i=? i$
I NEG big-NEG
'I am not big'

(251) kata gaddaSuni Pi=ma munnuৎuni 'I am not big, I am small' I big NEG-NEG small

(252) ayma sinni wura $=t u$ 'my wife is at home' woman my house-from

For the past, the verb ida 'to be' is used.

(253) ayma sinni wura=tu $k u=i ́ d a \quad$ 'my wife was at home' woman my house-from 3S.F-be_there.PST

(254) kata Songotitta 'I am Ongota' I O.SING

(255) kiPita Songota 'they are Ongota' they $\mathrm{O}$.

(256) a. kata Songota=?i 'I am not Ongota' I O.-NEG

b. kata Songotitta=?i 'I am not Ongota' I O.SING-NEG

(257) $w u r a=k o$ áddate giddeYeta lámbano $\mathrm{ku}$ sinni house-DET there big.P two 3S.F my 'those two big houses are mine'

4.7. Relative clauses. The following rules apply:

- relative clauses precede the matrix clause;

- the end of the clause is marked by the Indirect Clitics of third person =na 'him' if its head is masculine, and =ta 'her' if feminine (cf. 3.3.4). 
- the relative verb is generally not preceded by a Subject Clitic; this is especially the case when the subject of the relative is also the subject of the main clause.

(258) naxani inta=nki áddate kara qáfini=na aza sinni yesterday man-DET there fish fish.PROG-him sibling my 'that man who yesterday caught the fish is my brother'

(259) inta kara qáfini=na ka=yób

man fish fish.PROG-him 1S-see.PST

'I saw the man who caught the fish'

(260) ayma $=k o \quad$ janta ifan=ta $\quad k a=t s i ́ i n i$

woman-DET you marry.PST-her 1S-know.PROG

'I know the woman you married'

(261) ayma $=k o \quad$ kita ífan=ta $\quad k a=t s i ́ i n i$

woman-DET he marry.PST-her 1S-know.PROG

'I know the woman he married'

(262) ayma maara xódi=ta aza sinni

woman child generate.PST-her sibling my

'the woman who gave birth to a child is my sister'

(263) ayma $=k o \quad$ janta ifan=ta maara $k u=x o ́ d i$

woman-DET you marry.PST-her child 3S.F-generate.PST

'the woman you married gave birth to a child'

The presence of the Object Clitic representing the head is excluded if the relative clause contains an Object Clitic.

(264) inta kimiša cák=ta $k i=t i ́ b$

man crocodile eat.PST-her 3S.M-die.PST

'a man who eats a crocodile dies' (crocodile is feminine)

not: *inta kimiša cák=ta=na $\quad k i=t i ́ b$

eat.PST-her-him

(265) inta kara $j i=t a \quad$ aza sinni

man fish shoot.PST-her (=it) brother my

'the man who caught fish is my brother'

(266) inta=ko burinki caৎáw=ki ki=róota aza sinni man-DET today river-to 3S.M-go.PST brother my 'the man who today went to the river is my brother'

In negative relative clauses:

- the Subject Clitic is present, followed by the Negative marker ma, which, evidently, cannot stay alone before the verb; 
verb;

- the suffixed negative marker $=$ ?i generally does not appear after a relative

- the end of the clause is not marked by =na 'him' if its head is masculine, and by $=t a$ 'her' if feminine.

(267) inta cata $k i=m a=c a ́ k \quad$ aza sinni

man meat 3S.M-NEG-eat.PST brother my

'the man who did not eat meat is my brother'

(268) inta $=n k i \quad k a r a ~ k i=m a=j i ́=t a$

aza sinni

man-DET fish 3S.M-NEG-shoot.PST-her (= it) brother my

'the man who did not catch fish is my brother'

(269) inta ayma $k i=m a=i f a m \quad$ aza sinni

man woman 3S.M-NEG-marry.PST brother my

'the man who didn't marry the woman is my brother'

4.8. Object and subject sentences. The Infinitive (cf. 3.9.8) is used in the object or subject clause, which precedes the matrix clause: 12

(270) kata jami šu?una=me šúgucco $k a=h a ́ a b i n i$

I you.OBJ butter-with smear.INF 1S-want.PROG

'I want to smear you with butter'

(271) kata tora=me binta cóqqo ka=háabini

I spear-with animal hit.INF $1 S$-want.PROG

'I want to hit the animal with the spear'

(272) wákko kata $k a=m a=h a ́ a b i n i=? i \quad$ 'I don't want to fall' fall.INF I 1S-NEG-want-NEG

(273) múxele abba 'to laugh is good' laugh.INF good

4.9. Sentence embedding. The embedded clause always precedes the matrix clause.

(274) hawki ki=róo

$$
k a=m a=t s i i[n i=\text { Ri] }
$$

where 3S.M-go.PST 1S-NEG-know(.PROG-NEG)

'I don't know where he went'

(275) haw=to ki=ée

$k a=m a=t s i i[n i=$ ?i]

where-from 3S.M-come.PST 1S-NEG-know(.PROG-NEG)

'I don't know where he came from'

12 Ts also uses this infinitive construction. 
(276) haw $=t u \quad k i=e ́ e n i \quad k a=m a=t s i ́ i[n i=? i]$ where-from 3S.M-come.PROG 1S-NEG-know(.PROG-NEG) 'I don't know where he comes from'

(277) $y o o b a=k o$ mila ée káta $k a=m a=t s i ́ i[n i=? i]$ people-DET how-many come.PST I 1S-NEG-know(.PROG-NEG) 'I don't know how many men came'

(278) báre $k i=a ́ s k a m \quad k a=m a=t s i ́ i[n i=? i]$ when 3S.M-go.PST 1S-NEG-know(.PROG-NEG)

'I don't know when he went'

(279) haka ée $\quad k a=m a=t s i ́[$ [ni=?i]

who come.PST 1S-NEG-know(.PROG-NEG)

'I don't know who came'

(280) kata $k u=m i \quad$ mórommo ka=háabini

I 3S.F-with speak.INF 1S-want.PROG

'I want to speak with her'

(281) kata $k u=m i \quad$ mórommo $k a=m a=\hbar a ́ a b i n i=? i$

I 3S.F-with speak.INF 1S-NEG-want.PROG-NEG

'I don't want to speak with her'

(282) haka $i=y o ́ b \quad$ Sále na=ku 'tell me whom you saw' who 2S-see.PST tell.IMPV.S 1S-for

(283) barama $k u$ éeyo $k a=h a ́ a b i n i \quad$ 'I want her to come tomorrow' tomorrow 3S.F come.INF 1S-want.PROG

(note the irregular Infinitive of ée 'to come' with epenthetic/y/)

(284) na $i=y o ́ b \quad$ Sále na $=k u \quad$ tell me what you saw' what 2S-see.PST tell.IMPV.S 1S-for

(285) barama $i=$ róota =na Sále na=ku tomorrow 2S-go.PROG-and tell.IMPV.S 1S-for 'tell me if you are going tomorrow'

Specific sentence-subordinating (or coordinating?) devices are =na 'and' and $=b a$ 'if' (possibly borrowed from Ts.).

(286) ayki šera $i=m a=n a ́ S \quad n a=k u=n a$ barama tora $k a=m a=n a ́ S=i$ today knife $2 \mathrm{~S}$-NEG-give me-for-and tomorrow spear $1 \mathrm{~S}-\mathrm{NEG}$-give-NEG 'if today you don't give me your knife, tomorrow I won't give my spear'

(287) kimiša inta $k i=h a ́ q=b a \quad k i=j i[=n i]$ crocodile man 3S.M-bite-and 3S.M-kill(.PROG) 'if a crocodile bites a man, it kills (will kill) him' 
4.10. Coordination. Sentences are often linked without marking:

(288) janta rootá hanca=ko gadá 'go and cut the tree!' you go.IMPV.S tree-DET cut.IMPV.S

Apart from =na 'and' and = ba 'if' (cf. 286, 287), a partial list of coordinating elements-all of them clitics-follows here below.

$=$ ?i 'also'

(289) $k i=$ ?i gaddafuni 'he too is big'

3S.M-too big

$=m a$ 'but'

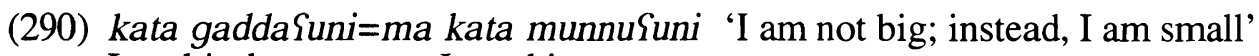
I big-but I big

$=m u$ 'or'

(291) caSawa=mu eefi háabini 'do you want water or milk?' water-or milk want.PROG

4.11. Focus. As far as one can tell from our data, the absence of the Subject Clitics in declarative sentences is a focus-marking device, as shown above in nominal sentences (v. 4.6), and in:

(292) gabare gás $k i \quad$ 'a snake bit him' snake bite.PST 3S.M

No specific focus-marking element has been identified, except for the following contrastive-marking repetition of a Subject Clitic.

(293) $k a=$ ?i $k i=k i=a ́ m \quad$ 'not me; he was (to do it)!'

I-NEG 3S.M-3S.M-be

As anticipated, the absence of the Subject Clitics in Content and Polar Questions (cf. 4.4.1., 4.4.2) is probably to be explained on the basis of the inherently focalized status of the word on which the question bears. 


\section{Ongota lexicon}

Words are arranged in alphabetical order; vowel-initial words are listed all together at the beginning, followed by / $/$ /-initial words. Ts'amakko and a few other loans are underlined. Verbs are reported under their stem-form; the Imperative Singular and Plural forms are given whenever available.

aaka women; females

aame- to rest

IMPV.S: aamé; IMPV.P: aaméta

abba good; beautiful; well

abun- to embrace, to lull (Ts)

IMPV.S: abuná, IMPV.P: abúnta

áddate that (faraway); there

afa eye; afa axay $k a=t u$ - 'the eye hurts me' (calque from Ts)

ah- to lose

IMPV.S: ahá; IMPV.P: áhta;

CAUS ahsan to make lose

IMPV.S: ahsaná; IMPV.P: ahsánta

aka foot; leg

akka grandfather (both father's father and mother's father)

(ak)kálbano one

akkuyte father's older brother/sister

algas- can, to be able (Ts)

am- to be

ama breast; ama= to iifa - nipple

("breast's mouth"; calque from Ts)

amate white sorghum (Ts)

ame- to suck

IMPV.S: amé, IMPV.P: améta

CAUS amsan to make suck

IMPV.S: amsaná, IMPV.P: ansánta

andulle heron (cf. bargada)

ardo ox

arka hartebeest (Ts)

ármata catarrh, mucous

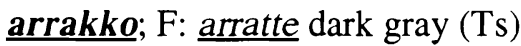

árre donkey (Ts)

aryitta friend (Ts)

askam- to go

IMPV.S.: —; IMPV.P: askánta

ašana how?

ašawa earring (Ts)

ášinkuni sister's son

áttomuni white

átolla pigeon (Ts atole)

áxaco sun

axay - to rise, stand up

IMPV.S: axayá; IMPV.P: axáyta

ayki now

ayma woman, wife; female (P: aaka)

ayta which?

ayyane mother

aza sibling

ázole sp. of edible grass (Ts)

ee- to come (irr. IMPV.: háy/háyta);

IMPV.NEG: ínti ma éa - 'don't come!'

eeda relative (Ts)

eefi milk; tear

eela children

ekkešad- sad, to be (Ts)

IMPV.S: ekkešadá

ékkite loud; a lot (Ts)

ella, elella oneself

erangolle necklace of white and red beads (Ts) 
ereha foetus; ereha $k u=a ́ h$ 'she had a miscarriage'; kuta ereha $k a=a h s a n$ 'I make her have a miscarriage'

erehi?- to become pregnant

IMPV.S: erehiPá, IMPV.P: erehíita;

CAUS erehsan- to make pregnant

IMPV.S: erehsaná,

IMPV.P: erehsánta

erehte P: erehiwa pregnant (a Ts loan?)

íccama (=ícca=ma ?) slowly; a little

bit; softly; ícca=ma caká - 'eat a little bit!'

ifam- to marry

IMPV.S: ifamá, IMPV.P: ifánta

igire daughters; girls

ii?a arm; hand; finger

iida there is/are

iifa mouth; language; ífa Songota the Ongota language; inta iifa ki ma išéeni - dumb ("man who doesn't have a mouth")

iila sons; boys

iište neck (cf. also denge)

ilaša bushpig (Ts ilaaša)

inkena so; this

innakko spider (Ts)

inta man; husband; male ( $\mathrm{P}$ : yooba)

inta akkálbano twenty ('one man'; calque from Ts qawko mume 'a whole man')

ippa door

irgaYa axe (Ts irgaYo)

irmatte termite (Ts irmatte)

ista eight

išee- to bring; to have

IMPV.S: išée, IMPV.P: išéeta

iške- to play

IMPV.S: išké, IMPV.P: iškéta

išma play (n.) itima tooth; itima miintite incisor

(calque from Ts ilge miinate)

olla village, settlement

oobde son's daughter (Ts?)

oofe beans (Ts)

oof ko son's son (Ts?)

orga SING: orgitta Hamar (Ts)

orma tall (Ts)

oršatte rhinoceros (Ts)

ottako calf (Ts)

óxaya lion

oxoni fire

ucce- to pour, fill (Ts)

IMPV.S: uccé, IMPV.P: uccéta CAUS uccaš to make fill

IMPV.S: uccašá, IMPV.P: uccášta

uke elephant

úkubu sister's husband

ukubu sp. of gray fish with many scales

uppatte amniotic fluid (Ts)

Sabuya uncle

Sabuyte grandmother (both father's mother and mother's mother or father's/mother's older sister)

Sad- to lick

IMPV.S: Yadá, IMPV.P: Yádta

CAUS Sadas to make lick

Sádaba tongue

Sádala bad, ugly

Sadda father's older brother's wife or son (Ts Sadda 'friend, brother')

Sádiba elder, old man; husband

Sahaye bird

Yálala kind of dove or pigeon (Ts xalle)

Sale Gawwada (and other Dullayspeaking groups of the highlands; Ts)

Sale- to tell

IMPV.S: Salé, IMPV.P: Saléta 
Sangaba big acacia umbrelliphera

Sangat- to mix

IMPV.S: Sangatá, IMPV.P: Sangátta

Sango wisdom tooth

Sar- to stink

IMPV.S: Gará, IMPV.P: Sárta

Sari coffee (Ts)

\{ázane younger brother (Ts Sazo)

Yebefe- to vomit

Siqqiši?- to sneeze

IMPV.S: Giqqišîi?a, IMPV.P: Giqqišîita

Sigad- to hiccough (Ts)

IMPV.S: Giqadá, IMPV.P: Giqádta

Sizza root, vein (Ts hezze)

Yongóta SING: Songotítta Ongota (the people and the area); Songót $=$ to from Ongota

=ba and

baahante bow (Ts)

baara armpit (Ts báaro)

baaxa dirty

baaye father

báaye munnuSuni father's younger brother ["little father"]

ba?, ba?ate there is not (Ts); neg. of ida baYatuni poor

baYce- to carry (on the back)

$\underline{\text { badio }}$ pelican (Ts)

badde all

bagaye small portable container for water

bagada back (body part)

bagat- to run (P subj.)

IMPV.P: bagátta;

CAUS bagtis to make run (P obj.)

IMPV.P: bagtísta

balYasa face

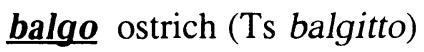

balo shrew bannádda beetle (Ts)

baq- to die (P stem?)

IMPV.P: báqta

baqa excrement

bagas- to divide, share (Ts)

barám, barama tomorrow

bárgada heron (Ts)

bargadde collar-bone (Ts)

bari when?

barla white-browed sparrow weaver

(Ts barlo)

báya Sa buffalo

be?e- to give

IMPV.P: be?é, IMPV.P: be?éeta

behatto left (Ts)

bera year (Ts berko)

berre- to touch (Ts)

IMPV.S: berré, IMPV.P: berréta

bia land (Ts bie)

bih- to lose

IMPV.S: 6ihé, IMPV.P: Gihéta

CAUS bihsan to cause to lose

IMPV.S: Bihsaná, IMPV.P: Bihsánta

biibe- to chase, send away

IMPV.S: biibé, IMPV.P: biibéta

bine head; hair

binta wild animal

bos- to be hard, strong; to be dry

boda saliva

bor chest, stomach (Ts borko); kata

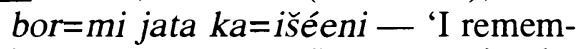
ber you' ("I carry/have you in the chest")

IMPV.S: $b o r=m i$ išée

IMPV.P: bor=mi išéeta

boraho seed (Ts boraho)

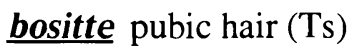


boš- to pick up, collect

IMPV.S: boošá, IMPV.P: bóošta;

MID boše to pick up, collect

IMPV.S: boošé, IMPV.P: boošéta;

CAUS bošisan to make collect

bote wild peas (Ts)

boye- to cry

IMPV.S: boyé, IMPV.P: boyéta

bus- to dry up, become dry

IMPV.S: 6uYá, IMPV.P: 6úita

bud- to spit

IMPV.S: budá, IMPV.P: búdta

buhad- to bark (subj.: dog)

bul- to pull out

IMPV.S: bulá, IMPV.P: búlta

PASS bulam to be pulled out

MID buli? to pull out

CAUS bulsan to make pull out

\section{burinki today}

buusa belly (Hamar busa 'lower belly' [Fleming et al. 1992/93: 210]);

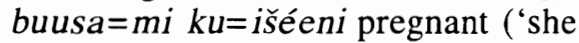
has a belly')

buute sp. of snake (Ts)

caYa (masc.) stone; grinding stone (below)

caYaw- to drink

IMPV.S: ca@awá, IMPV.P: caßáwta CAUS caßawšan- to make drink; IMPV.S: caßawšá, IMPV.P: caYáwšta

caYawa water; river; ca\aw=to $k i=s ̌ a ́ b$ 'he crossed the river'; ca $\{a w=$ to gúskuto ki=zóguy 'he swam in the river'

cak- to eat

IMPV.S: caká, IMPV.P: cákta; bine cáki=ka 'my head hurts ("eats") me' CAUS cakšan- to make eat IMPV.S: cakšaná, IMPV.P: cakšánta caq- to hide

IMPV.S: caqá, IMPV.P: cáqta

MID caqi- to hide for oneself

IMPV.S: caqiiá, IMPV.P: caqíita

caqmam- to hide oneself

IMPV.S: caqmamá, IMPV.P: caqmánta

CAUS caqšan- to make hide

IMPV.S: caqšaná, IMPV.P: caqšánta

carba thin

cárkamuni green

carke dew (Ts)

cata meat

cawo gun, rifle (cf. Ts qawa?)

caxtip- to ask

IMPV.S: caxtîá, IMPV.P: caxtíita

cayde pen, enclosure (Ts)

ciSi little stone, pebble (cf. caßa)

cig- to sew

IMPV.S: cigá, IMPV.P: cígta

cikila elbow (Ts tsekila)

cincaqe ant (cf. Ts shinshalle?)

coma ten; coma akkálbano eleven;

coma lama twelve; coma zeha thirty

comba lung (Ts somba)

conqorte mud

coq - to hit, pierce, spear, sting; káta tóra=me $k a=c o ́ q$ 'I speared with the spear'; $k a=c o ́ q$ ba $k a=j i$ 'I speared and I killed'

IMPV.S: coqá, IMPV.P: cóqta coqi?- to hit for oneself (w/spear)

IMPV.S: coqiiá, IMPV.P: coqíita

CAUS coqšan- to make hit (w/spear)

IMPV.S: coqšaná, IMPV.P: coqšánta

corkoto sp. of fish, not eaten

cuutta red-fronted tinkerbird (Ts suutta) 
daaf - to become blind (Ts)

IMPV.S: daafá, IMPV.P: dáafta

daafakko F: daafatte; P: daafayke blind (Ts)

daafis- to make be blind (Ts)

IMPV.S: daafisá, IMPV.P: daafísta

dábarsa genet

dábaša baboon

$\underline{\text { dabb }}$ - to miss the target (Ts)

IMPV.S: dabbé, IMPV.P: dabbéta

$\underline{\text { daggab }}$ - to arrive (Ts)

IMPV.S: daggabá, IMPV.P: daggábta dággabos- to make arrive

dakkakko F: dakkatte; P: dakkayke deaf; stupid (Ts)

dam Ya giraffe (Ts)

dambalasitte sp. of snake (Ts dambala 9 )

dangadangaco porcupine (Ts)

dangad-to plough; to do, make, work

IMPV.S: dangadá, IMPV.P: dangádta

daqse [daqša] long-crested eagle

darbo skin; hide

dat- to make fall

IMPV.S: datá, IMPV.P: -

deela hole

denge neck (Ts; cf. also iište)

dibita cat

diga owlet (Ts díge)

diig- to add water (and other liquids)

(Ts); caßáw cata=ki $k i=d i i ́ g$ 'he added water to the meat'

IMPV.S: diigá, IMPV.P: diigta

diigam- to be poured (?)

MID diigi?- to pour into

IMPV.S: diigîá, IMPV.P: diigíita

CAUS diigas- to make pour

IMPV.S: diigasá, IMPV.P: diigásta cf. also tu? -'to add (things, one by one, or other liquids)' and fa? 'to add salt (sand, earth)'

diira sp. of small fish, with many spines

dizza klipspringer (Ts)

do?osa waterbuck (Ts do?osko)

doore sp. of fish

dúbaza mongoose (Ts)

dullaya the Weyt'o river (Ts dullayko)

dunko pupil of the eye (Ts)

dákkamuni black

day to twist the firesticks

IMPV.S: đáya, IMPV.P: đáyta

dayte firesticks (together)

desse kidney (Ts)

deeša poison; medicine

dehad-to reach (someone) (Ts)

IMPV.S: đehadá, IMPV.P: dehádta

dehe- to stop (intr.); P stem: aame-

IMPV.S: đehé, IMPV.P: aaméta

dibba hundred (Dullay)

diim- to plunge (Ts diim)

IMPV.S: diimá, IMPV.P: diinta

donka hornbill (Ts donke)

dugate truth (Ts)

fa?- to kindle; to add (salt, sand, earth), to put into; kita soqo ki=fá? 'he added salt'

IMPV.S: faPá, IMPV.P: fá?ta

fa?am- to be added

fa?i- to add for oneself

IMPV.S: fa?iłá, IMPV.P: farîta

CAUS fa?san- to make add

IMPV.S: fa?saná, IMPV.P: fa?sánta

cf. diig- 'to add water (and other

liquids)' and tu?- 'to add (things, one by one)'

fad-to put down; IMPV.P: fádta 
fálde [pálde] arrow's point (Ts pálde)

farat- to send away

IMPV.S: faratá, IMPV.P: farátta

CAUS faratsan- to cause to send away

IMPV.S: farsaná, IMPV.P: farsánta

fip- to milk

IMPV.S: fîá, IMPV.P: fîta

fidis- to whistle (Ts fidis)

IMPV.S: fidisá, IMPV.P: fidísta

fili?- to comb (Ts fil)

IMPV.S: filipá, IMPV.P: filîta

filma comb (Ts)

foof- to leave; to emerge (P. stem)

IMPV.P: fóofta

CAUS foofsan- to make leave (P. obj.)

foolo cloud (Ts poolo)

fuga SING: fugitta Amhara

fulfula [pulpula] sacrum (anat.)

gaba bush duiker (Ts)

gabare snake

gaddaYuni P: giddefeta big; old

gallabdi evening (Ts gallaw?; or areal word?)

\section{game corn (Ts)}

garaboko shin (Ts garaboko)

gats- to climb; to come out

IMPV.S: gatsá, IMPV.P: gá[t]sta

gawarsa bateleur (Theratopius ecaudatus; Ts gawarakko)

gawšo chin (Ts gawso)

gef- to belch (Ts)

IMPV.S: gefá, IMPV.P: géYta

geccate P: geccayke old (Ts) (not used for S.M)

geres- to steal (Ts)

IMPV.S: gere\{á, IMPV.P: geréYta

gere@a thief (Ts) gergitto enemy (Ts)

gešante firestick (horizontal) (cf. Ts gešante 'woman'?)

gibila knee (Ts gibilko)

gibisa femur (Ts gubusko)

gidana hair

gillata fish eagle (Ts giloto)

gira [haji ki...] to lighten

girib-to become night

gis- to say; dugate $k a=g i s i=j a n t u$ 'I

tell you the truth'

IMPV.S: gisá, IMPV.P: gísta;

MID gisi?- to say

IMPV.S: gisi?á, IMPV.P: gisîita

giš- to enter; to understand

goga white-headed buffalo weaver (Ts gohile)

gola beer

gollanke nine (Ts)

gorgora beehive

gosa tribe (Amh)

goxe to put out

goyangoyo a sp. of fish, not eaten

gúbale rabbit (Ts)

gufas- to cough (Ts)

IMPV.S: gufa Yá, IMPV.P: gufáita

gula a sp. of lizard (?) (Ts)

gúlbata strength; inta gúlbata $=m i$

$k i=$ dángadi 'the man worked with strength'

gulma kind of big calabash (Ts)

gúmara throat

gunture hartebeest (Ts)

gura such as, like (Ts)

gurba؟a little swift (Ts gurbaৎakko)

gure hunting dog

gurtulla galago; bush baby? (Ts gurtullo) 
gúskutu inside

gusunte navel (cf. also handura)

gutal- to jump; to dance, sing

IMPV.S: gutalá, IMPV.P: gutálta

CAUS gutalis- to make jump, dance, sing

IMPV.S: gutalisá, IMPV.P: gutalista gutula stump (Ts gutsunko)

gas- to bite

IMPV.S: gaYá, IMPV.P: gáita

gad- to cut

IMPV.S: gadá; P. stem: qits- (Ts)

gadip- to cut for oneself

IMPV.S: gadiłá, IMPV.P: gadîta

CAUS gadsan- to make cut

IMPV.S: gadsaná, IMPV.P: gadsánta

gar- to be happy

CAUS garsas - to cause to be happy;

IMPV.S: garsasá, IMPV.P: garsásta

g $\underline{\text { as }}$ - to hunt (see also qoš) (Ts gaasi 'to fish')

gay - to run

IMPV.S: gayá; P stem: bagat-

CAUS gaysan to make run

IMPV.S: gaysaná

gefe side

ges- to shave

IMPV.S: filipá, IMPV.P: filîta

gesi? to shave oneself

IMPV.S: gesi?á, IMPV.P: gesí?ta

gina fa rib (Ts)

ginano mosquito

goh- to grow (Ts)

IMPV.S: gohá, IMPV.P: góhta CAUS

gohis to make grow

IMPV.S: gohisá, IMPV.P: hohísta

goi?- to take, get

IMPV.S: goi?á, IMPV.P: goíita

guy - to kindle the fire

IMPV.S: guyá, IMPV.P: gúyta haka who

handura navel (Ts handurte; cf. also gusunte)

haš- to hear, listen

IMPV.S: ašá, IMPV.P: ášta

hat- to clap the hands

hawki to where?

hawtu from where?

háy P: háyta 'come!' (irregular IMPV of ée 'to come')

hobat-, hobe- to wash

IMPV.S: hobatá, IMPV.P: hobátta hobati?- to wash oneself

IMPV.S: hobatiPá, IMPV.P: hobatíita

hokam- to exchange (P. subject) (Ts ooki))

IMPV.P: hokánta

haabi- to want (always as háabini PROG)

haaši leaf; grass (Ts Saaško 'grass')

habura wind (Ts háburko)

had- to collect (stem)

IMPV.S: hadá, IMPV.P: hádta

MID hadi- to collect, pick up (P. stem)

IMPV.P: hadita

CAUS hadsan- to make collect

IMPV.S: hadsaná, IMPV.P: hadsánta

hágalo edible leaves

hagun- smell good, to

IMPV.S: haguná, IMPV.P: hagúnta

haji rain

halo calabash (Ts halte)

hanca tree; wood

hangararo worm (Ts)

hat- to hunt, shoot; kata cawo=me binta $k a=h a ́ t$ 'I shot an animal with the rifle'

IMPV.S: hatá, IMPV.P: hátta; binta noqótta=ba gída hátta 'you (P) take aim and shoot the animal!' 
hed-to close, tie

IMPV.S: hedá, IMPV.P: hétta

hee- to like, love (always PROG: héeni)

hizge star (Ts hezge)

hólbatuni short

hooka chest (Ts heko)

hugu itching

jaaka child, baby (P: eela)

janta jaami you

jiP- to kill; to hit; to extinguish (fire) (see

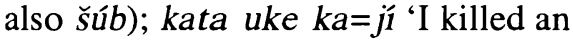
elephant'

IMPV.S: jîá, IMPV.P: jîta

juuka daughter; girl (P: igire)

kaada rope

kaanna since long ago (Ts)

káasala molar (Ts)

kab- to wait

kacce shoulder (Ts)

káfaYa sp. of snake

kala bead

kamurre, $\underline{\text { kamurko }}, \underline{\text { kamurte }}$ rich (Ts, areal)

kanna kanna in a hurry (Ts)

kano vagina; $k a n u=d u$ an insult

kara fish (general term); sp. of big black fish (cf. Ts xarre?)

kara power, authority (?); used in the sentence: inta kara $k i=$ roota 'he is powerful'

karawa colobus (Ts karawko)

karbo bird

kat- to leave; to come out, emerge

IMPV.S: katá; P stem: foof-

kawlal cheek

kaykitta bridegroom (Ts)

kaykitte bride (Ts) keesa other

kere headrest (Ts)

kermayle zebra (Ts?)

kidisa cooking stones

kimiša crocodile

kirde testicle (Ts)

kirinca ankle (Ts)

kiti road

kobis- to pinch (Ts)

IMPV.S: kobisá, IMPV.P: kobísta

kol- to come back, return (Ts)

IMPV.S: kolá, IMPV.P: kólta

MID kola- to come back, return

IMPV.S: kolé, IMPV.P: koléta

CAUS kolsan- to make return

IMPV.S: kolsaná, IMPV.P: kolsánta

kolba another time, again

kolokolfo hamerkop (or cormorant, or

bishop bird?; cf. Ts qolaqolfo)

komba beads necklace (Ts)

konqayle goose

koola wing (Ts koolo)

koom- to dig

IMPV.P: koomá, IMPV.P: kóonta

kórkiša [=sa] francolin or spurfowl (Ts korkiša)

kórome fishing hook (Ts kormicco)

kox- to leak

CAUS koxis- to make leak

kubis flower (cf. Ts bisko?)

kufe tortoise (Ts)

kuhhen fruit

kúlula guinea-fowl (Ts kulule)

kum- to finish (intr.) (Ts kum)

IMPV.S: kumá, IMPV.P: kúnta

kunkumitte cheek (Ts)

kúrruba crow, raven (Ts kúrrube) 
kuskuso hyena (cf. Ts kuškušo cock's mane'?)

kuše- to beat, hit (obj.: P)

IMPV.P: kušé, IMPV.P: kušéta

kutsa [kutša] vulture (Ts kutso)

kuttunko mountain (Ts kuttunko)

laahko arrow (Ts)

laalbe dress

laale oribi (Ts)

laamaxode twins ('2nd-born')

láYakko plain (Ts láYakko)

lama two (Cushitic)

lattu soft (Ts)

lax- to mix (tr.) (Dullay)

IMPV.S: laxá, IMPV.P: láxta laxamto mix (intr.)

IMPV.S: laxamá, IMPV.P: laxámta

leeYa moon; month (Ts leefo)

leeleSa uvula

lool- to be, get angry

IMPV.S: loolá, IMPV.P: lóolta

CAUS loolsan- to cause to be angry

IMPV.S: loolsaná, IMPV.P: loolsánta

luqqa cuckoo or coucal (Ts lukkale)

maaqa sp. of lizard (Ts maaqa)

maara 1. son, child (male), boy; 2. sun-

bird (Ts, this meaning only)

mac'e sp. of edible grass (Ts)

mad- to go away; to take a different road (Ts)

IMPV.S: magá, IMPV.P: mágta

MID maggi?- to go away

IMPV.S: magf'é, IMPV.P: maggéta

CAUS magis- to cause to take a different way

IMPV.S: magisá, IMPV.P: magísta

CAUS magsan- to chase away; to cause to take a different way

IMPV.S: maǵsaná, IMPV.P: mađsánta malal- to be tired (Ts)

IMPV.S: malalá, IMPV.P: malálta

malalsi- to tire

IMPV.S: malalisá, IMPV.P: malalísta

marrahe $\mathrm{sp}$. of edible grass(Ts)

marróte forearm bracelet (Ts)

marte she-calf; marte orda he-calf

martsa little acacia umbrelliphera (Ts)

maš- to cut with a knife, slice; to slaugh-

ter (for 'to cut' in general see had-);

kata šera=me barama kara ká=maš

'tomorrow I'll cut the fish with a knife

IMPV.S: mašá, IMPV.P: mášta

mayye- to kiss (Ts)

IMPV.S: mayyé, IMPV.P: mayyéta

mee؟- to shout (subj.: animal)

mekente sterile (F; Ts); for male: moolo tiibto

merja antelope (Ts)

meša name

miPa how much/many?

mic'a bone

middo wrist bracelet (Ts)

midisa grinding stone

miditte clitoris; miditti $=d u$ an insult

milmille sp. of fish, not eaten

mirPamatte intestine (Ts mirma?atte)

mirila cheetah; leopard (Ts moralle)

mizigitte right $(\mathrm{Ts})$

moolo penis; moolo siidu an insult; moolo tiibto sterile (said of male;

'the penis is dead')

moora light gray (Ts)

moqotte frog (Ts muqoite)

morom- to speak

IMPV.S: moromá IMPV.P: morónta

MID moromi?- to converse

IMPV.S: moromiłá, IMPV.P: moromíita 
CAUS moromis- to make speak

IMPV.S: moromisá, IMPV.P: moromísta

CAUS-MID moromsan- to make speak

IMPV.S: moromsaná,

IMPV.P: moromsánta

moyle gerenuk (Ts moyle)

munnuSuni P: minSeta little, small; young

múralla kori bustard (Ts múrale)

muta crane (Ts mute)

muusko sorghum; muusko roomini red sorghum

muuts- to answer; to give back

IMPV.S: muutsá, IMPV.P: múutsta

muxe- to laugh

IMPV.S: muxé, IMPV.P: muxéta

CAUS muxsan- to make laugh

IMPV.S: muxsaná, IMPV.P: muxsánta

naS- to give

IMPV.S: na@á, IMPV.S: náita

CAUS nassan- to cause to give

naYana food

nabad- to hate (Ts)

IMPV.S: nabadá, IMPV.P: nabádta

nágayko peace; a greeting (Ts)

nah- to be surprised, shocked

IMPV.S: nahá, IMPV.P: náhta

CAUS nahsan- to surprise, to be a

cause of surprise

IMPV.S: nahsaná, IMPV.P: nahsánta

$n a=k u$ why? ("what-for")

narfi needle (Amh)

naxani yesterday

nilla little fish used for bait

nitsina many

nogot- to look, aim at (Ts)

IMPV.S: noqotá, IMPV.P: noqótta

noqotip- look, aim at, to

IMPV.S: noqoti?á, IMPV.P: noqotíita qaabakko sp. of fly (tse-tse?; Ts)

qaade-to lie down

IMPV.S: qaadé, IMPV.P: qaadéta

gaara monkey (Ts qaarakko)

qaba saucepan

qafe- to fish

IMPV.S: qafé qappé,

IMPV.P: qaféta qappéta

galaya golden cat; hyena (Ts qalate)

qalte sp. of big white fish

gane day (Amh); qane badde always;

qane qane sometimes (calque from

Ts)

qaqayo little frog

qaqge bark (Ts qaqqatte)

qaske dog

qaw - to burn (intr.); to catch fire;

qawad-to burn (intr.)

gawte pumpkin (Ts)

goba finger (Ts qobakko)

gode snail (Ts)

gola animal (domestic) (Ts qole)

qolo goat

gooš- to hunt (see also has) (Ts qooši)

qumu container (general term)

raaw- to finish (tr.) (Ts raawi)

IMPV.P: raawá, IMPV.P: ráawta

rakke- to hang (Ts)

IMPV.S: rakké, IMPV.P: rakkéta

CAUS rakkis- to make hang

reekis- to mix (Ts)

IMPV.S: reekisá, IMPV.P: reekísta

reex- to go down

IMPV.S: reexá; P stem: ?

renta hippopotamus (Ts rento)

rewa $\mathrm{sp}$. of edible grass

rig- to smooth a skin with a stone (Ts?)

IMPV.S: rigá, IMPV.P: rígda 
riir- to shout (Ts riir)

IMPV.S: riirá, IMPV.P: ríirta

roo- to go

IMPV.S: rootá, IMPV.P: róotta

róomini red

roqinta heart

ruggi=tu in front of

rummahte SING: rummattitta Arbore (Ts)

saalta oryx (Ts šaalto)

sáamule ibis

sagayto wrist

sal- to wait (Ts sál)

IMPV.S: salá, IMPV.P: sálta

CAUS salis- to make wait (CAUS)

IMPV.S: salisá, IMPV.P: salísta

CAUS-MID salsan- to make wait

IMPV.S: salsaná, IMPV.P: salsánta

sarba calf (body part) (Ts sarba)

sayra dikdik (Ts sawro; cf. also séngere)

séngere dikdik (cf. also sayra)

sey flea (Ts)

sibila iron (areal word)

sidda before

siibde bow string (Ts siibde)

siida eyebrow (Ts sido)

siina nose

siinsad-to smell

IMPV.S: siinsadá, IMPV.P: siinsádta silbe yellow

silbe áttomuni light blue

('yellow+white')

silbe cárkamuni dark green

('yellow+green')

silbe dákkamuni blue

('yellow+black')

silbe róomini pink; violet

('yellow+red')

sippa [tsippa] sweat (Ts sippo) sira?a sp. of very small fish

sodda sister (Ts 'brother/sister-in-law')

sonon- to blow the nose

IMPV.S: sononá, IMPV.P: sonónta

sonqitte fingernail

soorto umbilical cord (Ts)

sogo salt (Ts)

sorra anus; sorra $=d u$ an insult

sug- to sniff (obj.: tampo 'tobacco')

IMPV.S: sugá, IMPV.P: súgta

suude flank

saPat- to be afraid

IMPV.S: ša?atá, IMPV.P: ša?átta

ふ̌aаһa urine; sperm

šaYalkuni older brother (Ts šaSalko)

šab- to cross

IMPV.S: šabá, IMPV.P: šábta

šammaৎši?- to yawn (Ts)

IMPV.S: šammaY̌sîá,

IMPV.P: šammaYšîta

šanne- to rest (on the headrest) (Ts

šánni)

IMPV.S: šanné, IMPV.P: šannéta

క̌eera knife

šmpola namaqua dove (Ts šumpulo)

ک̌ona bongo (or kudu?) (Ts)

šóokaya honey

šoon- to be hot; to be feverish, ill

IMPV.S: šooná, IMPV.P: šóonta

soqta male; bull; firestick (vertical)

soxe- to have sexual intercourse (subj.:

male; female: passive)

IMPV.S: šoxé, IMPV.P: šoxéta

ร̌oxo blood

šu?una butter

šu?a to anoint

IMPV.S: šuPá, IMPV.P: šú?ta 
šub- to kill (see also jir); kiPita šúb ella 'they killed each other'; kata barám kara šúbbo ka=róota 'I go fishing tomorrow'; korome $=$ me kara $k a=$ súb 'I fished with the fish hook'

šd- to cover; to dress (tr.) (Ts)

IMPV.S: šudá, IMPV.P: šútta šudam- to dress oneself

IMPV.S: šudamá, IMPV.P: šudánta;

CAUS šudas- to make dress, cover

IMPV.S: šudašá, IMPV.P: šudášta

šuguc- to anoint oneself

IMPV.S: šugucá, IMPV.P: šugúcta

šumaha sand (Ts šumahto)

taP- to take, catch

IMPV.S: ta?á, IMPV.S: tá?ta

MID ta?am- to take, catch

IMPV.S: taجamá, IMPV.S: ta?ánta

CAUS ta?san- to make take, catch

IMPV.S: ta?saná, IMPV.S: ta?sánta

\section{taSanta very}

taba thorn

tafo thigh (Ts tapo)

tag-, tagam- to sleep

IMPV.S: tagamá, IMPV.P: tagánta

CAUS tagsan- to make sleep

IMPV.S: tagsaná, IMPV.S: tagsánta

CAUS tagansan- to make sleep

IMPV.S: tagansaná,

IMPV.P: tagansánta

tágara shadow; met. place

tagats- to make go up

IMPV.S: tagatsá, IMPV.P: tagátsta

tahanke seven (Ts tahhan)

talaha four (cf. Ts salah?)

tamar- to learn (Amh)

IMPV.S: tamará, IMPV.P: tamárta

tampo tobacco (areal word)

taw- to build

IMPV.S: tawá, IMPV.P: táwta ta[w]i- to build for oneself

IMPV.S: tawi?á, IMPV.P: tawí?ta

taxay- to raise

IMPV.S: taxayá, IMPV.P: taxáyta

tereh- to make go down

IMPV.S: terehá, IMPV.P: teréhta

terekko dust (Ts teerikko)

tib- to die

IMPV.S: tibá, IMPV.P: tíbta

tiid- to put, store

IMPV.S: tiidá, IMPV.P: tíitta

CAUS tiidis-?, tiidas- to cause to put

IMPV.S: tiidisá, IMPV.P: tiidísta

CAUS tiidsan- to cause to put

IMPV.S: tiidsaná, IMPV.P: tiidsánta

tildo paradise flycatcher (Ts tílda)

tilile black kite (Ts)

tinniša potato (Amh)

tira liver (Ts tire)

tókoma heel (Ts tókonko)

tonnakko F:tonnatte; P:tonnayke lame; hump-backed (Ts)

toonte frankincense

toollo stick (Ts toolingo)

tora spear; tora $k i=n a ́ S=n a$ 'he gave me the spear'

tup- to add (things, one by one); naxani caSa $k i=t u ́$ ? 'yesterday he added a stone'

IMPV.S: tuPá, IMPV.P: tú?ta tupa- to be added

MID tu?i- to add for oneself

IMPV.S: tuPi?á, IMPV.P: tupi?ta

CAUS tu?san- to make add (sth. solid)

IMPV.S: tuPsaná, IMPV.P: tu?sánta

cf. diig- 'to add liquid' and fa?- 'to add salt (sand, earth)'

$=t u ? i$ also, too

tule buttocks (cf. Ts turde?)

tunaw- to be blunt (Ts tunay) 
tuuts to push (Ts tuuts)

IMPV.S: tuutsá, IMPV.P: túutsta

tsáamitsa louse

tsal- to curse

IMPV.S: tsalá, IMPV.P: tsálta

MID tsali?- to curse

CAUS tsalsan- to make curse

tsan- 1 . to be cold; 2. to heal (intr.), to recover

IMPV.S: tsaná, IMPV.P: tsánta

tsanafa six

tsaqam- to be salty, bitter

tsii- to know

IMPV.S: tsiiá, IMPV.P: tsíita

tsug- to lie down

$\underline{\text { tsuub- }}$ - to suck (Ts)

IMPV.S: tsuubá, IMPV.P: tsúubta

tsoonako honeybee (Ts ts'oonako)

waaga bat

wáala generic name for various species

of colored weavers

waaga African hoopoe (Ts wáaqo)

wáara forest

waga god

wak- to fall

IMPV.S: waká, IMPV.P: wákta

wal- to forget (Ts)

IMPV.S: walá, IMPV.P: wálta

wale panga (Ts)

was- to spend the day

IMPV.S: wasá, IMPV.P: wásta

wuyam- to call (Ts wuyá)

IMPV.S: wuyamá, IMPV.P: wuyánta

wohara he-goat

woki there

wowa ear

wunki here

wura house xa?- to do (irregular)

IMPV.S: xaašá, IMPV.P: xáašta

xaab- to scratch

IMPV.S: xaabá, IMPV.P: xáabta

xalle sp. of fish

xam- to become

IMPV.S: xamá, IMPV.P: xánta

xarat- to divide

xaraw [haji ki...] to thunder

xasod-to rejoice (Ts)

xibte lip (Ts)

xoP- to beat, hit; P stem: kuše-

IMPV.S: xơá, IMPV.P: xó?ta

$\underline{\text { xobbi five (Ts xobin) }}$

xod- to generate; to be born (with ISP a)

IMPV.S: xodé, IMPV.P: xodéta

xoona sheep

xot- to put down (P. stem)

IMPV.P: xótta

xotam- to go down (P. stem)

IMPV.P: xotánta

xur - to leave

IMPV.S: xurá, IMPV.P: xúrta

yaw- to stop, stand

IMPV.S: yaawá, IMPV.P: yáawta

CAUS yawsan- to make stop, stand

IMPV.S: yawsaná,

IMPV.P: yawsánta

yaayo jackal

yob- to see

IMPV.S: yobá, IMPV.P: yóbta

yooba men; males; people

zaarakko F: zaaratte; P: zaarayke crazy, stupid (Ts)

zabarna lie, falsehood

zanitte palm lines (Ts)

zaqe cotton (Ts záqe "cotton thread") 
zax- to grind

IMPV.S: zaxá, IMPV.P: záxta

MID: zaxi?- to grind for oneself

IMPV.S: zaxîá, IMPV.P: zaxíita

CAUS zaxsan- to make grind

IMPV.S: zaxsaná, IMPV.P: zaxsánta

zeha three (Ts zeh)

ziip- 1. to pull; 2 . to fart

IMPV.S: ziîá, IMPV.P: ziiipta

zilanqa sp. of lizard (Ts zilanqa)

zoborko worm (Ts)

zoguy- to swim (Ts zoguy-)

IMPV.S: zoguyá, IMPV.P: zogúyta

zoo?- to collect honey

IMPV.S: zoo?á, IMPV.P: zóo?ta

MID zoo?ip- to collect honey

IMPV.S: zoo?é, IMPV.P: zoo?éta

zooba beeswax

\section{English-Ongota index}

to add (things, one by one) tu?-; (obj. water and other liquids) diig

to be afraid ša?at-

all badde

also, too $=t u ? i$

Amhara fuga; SING: fugitta

amniotic fluid uppatte

and $=b a$

to be, get angry lool-

animal (domestic) gola; (wild) binta

ankle kirinca

to anoint $\check{u}$ ?a; (obj. oneself) šuguc-

another time, again kolba

to answer; to give back muuts-

ant cincaqe

antelope merja

anus sorra

Arbore rummatte; SING: rummattitta

arm; hand; finger ii?a

armpit baara

to arrive daggab

arrow laahko

arrow's point falde [palde]

to ask caxti?-

axe irgaSa

baboon dábaša

back (body part) bahada

bad, ugly Sádala

bark gaqqe

to bark (subj.: dog) buhad-

bat waaga

to be am-

bead kala; beads necklace komba

beans oofe 
to beat, hit xo?-; (obj.: P) kuše-; coq-

to become xam-

beehive gorgora

beer gola

beeswax zooba

beetle bannádda

before sídda

to belch gef-

belly buusa

big; old gaddaSuni; P: giddeSeta

bird (general term) karbo; Sahaye

to bite $g a s$ -

black dákkamuni

blind daafakko; F: daafatte ; P: daafayke; to become blind daaf-; to make be blind daafis -

blood šoxo

to blow the nose sonon-

to be blunt tunaw-

bone mic'a

bow baahante

bow string siibde

bracelet (forearm) marrote; (wrist) $\underline{\text { middo }}$

breast ama

bride kaykitte

bridegroom kaykitta

to bring; to have išee-

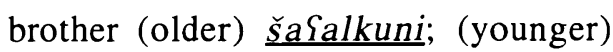

Sázane

buffalo báyaYa

to build taw-

to burn (intr.); to catch fire qaw-

bush duiker gaba

bushpig ílaša

butter šu?una

buttocks tule calabash $\underline{\text { halo }}$

calf ottako; she-calf marte

calf (body part) sarba

to call wuyam-

can, to be able algas

to carry (on the back) baice-

cat dibita

catarrh, mucous ármata

to chase, send away biibe-

cheek kawlal; kunkumitte

cheetah; leopard mirila

chest hooka

chest, stomach $\underline{\text { bor }}$

child, baby jaaka; P: eela

chin gawšo

to clap the hands hat-

to climb; to come out gats-

clitoris miditte

to close, tie hed-

cloud foolo

coffee Sari

to be cold tsan-

collar-bone bargadde

to collect had-(P. stem); (obj. honey) zoo?-

to comb fili? -

comb filma

to come ee-

to come back, return $\underline{\mathrm{kol}}$ -

container qumu

cooking stones kidisa

corn game

cotton zaqe

to cough gufas-

to cover; to dress (tr.) $\underline{\text { sud }}$ -

crane muta 
crazy, stupid zaarakko; F: zaaratte;

\section{P: zaarayke}

crocodile kimiša

to cross $\breve{s} a b$ -

crow, raven kúrruba

to cry boye-

to curse tsal-

to cut gad-

to cut with a knife, slice; to slaughter maš-

daughter; girl juuka; P: igire; son's daughter oobde

day qane

deaf; stupid dakkakko; F: dakkatte;

P: dakkayke

dew carke

to die $t i b$-; (P stem?) baq-

to dig koom-

dikdik sayra; séngere

dirty baaxa

to divide $x$ arat-

to divide, share baqas -

to do xa?-; dangad-

dog qaske

donkey arre

door ippa

dress laalbe

to drink caSaw-

to dry up, become dry buS-

dust terekko

ear wowa

earring ašawa

to eat cak-

edible leaves hágalo

eight ista

elbow cikila

elder, old man; husband Yádiba elephant uke

to embrace, to lull abun-

enemy gergitto

to enter; to understand gi $\breve{s}$ -

evening gallabdi

to exchange hokam- (P. subject)

excrement baqa

eye afa

eyebrow siida

face baliasa

to fall wak-; to make fall dat-

to fart zii?-

father baaye; father's older brother/ sister akkuyte

femur gibisa

finger qoba

fingernail sonqitte

to finish (intr.) $\underline{\mathrm{kum}}$-; (tr.) raaw-

fire oxoni

firestick gešante; dayte

to fish qafe-

fish (general term) kara

eagle (fish eagle) gillata; (long-

crested eagle) daqse [daqša]

fishing hook kórome

five $\underline{x o b b i}$

flank suude

flea sey

flower kubís

foetus ereha

food naYana

foot; leg aka

forest waara

to forget wal-

four talaha

frankincense toonte 
friend aryitta

frog moqotte

fruit kuhhen

Gawwada (and other Dullay-speaking groups of the highlands) Sale

to generate xod-

giraffe $\underline{\text { damia }}$

to give naS-; be?e-

to go roo-; askam-; to go away; to take

a different road mah-; to go down

reex-; to make go up tagats-; to

make go down tereh-

goat qolo; he-goat wohara

god waga

golden cat; hyena galaya

good; beautiful; well abba

goose konqayle

grandfather akka

gray (light) moora; (dark) arrakko;

$\mathrm{F}:$ arratte

green cárkamuni

to grind zax-

grinding stone midisa

to grow hoh-

guinea-fowl kúlula

gun, rifle cawo

hair gidana

Hamar orga; SING: orgitta

to hang rakke-

to be happy har-

to be hard, strong; to be dry boh-

to hate nabad-

head; hair bine

headrest $\underline{\text { kere }}$

to heal (intr.), to recover tsaan-

to hear, listen haš

heart roqinta heel tókoma

here wunki

heron andulle; bárgada

to hiccough 售ad

to hide caq-

hippopotamus renta

hole deela

honey šóokaya

honeybee tsoonako

hornbill donka

to be hot; to be feverish, ill šoon-

house wura

how? ašana

how much/many? mi?a

hundred dibba

to hunt, shoot has-; gooš-; hat-

hunting dog gure

hyena kuskuso

ibis sáamule

intestine mir?amatte

iron sibila

itching hugu

jackal yaayo

to jump; to dance, sing gutal-

kidney $\underline{\text { defse }}$

to kill; to hit; to extinguish (fire) ji?-; šub-

to kindle; to add (salt, sand, earth), to put into fa?-

to kindle the fire huy-

to kiss mayye-

klipspringer $\underline{\text { dizza }}$

knee gibila

knife šeera

to know tsii-

lame; hump-backed tonnakko; 
F: tonnatte; P:tonnayke

land $\underline{\text { bia }}$

to laugh muxe-

leaf; grass $\underline{\text { haaši }}$

to leak kox-

to learn tamar-

to leave xur-

to leave; to come out, emerge kat-; (P subj.) foof-

left behatto

to lick Sad-

lie, falsehood zabarna

to lie down qaade-; tsug-

like, love, to heeni-

lion óxaya

lip $\underline{\text { xibte }}$

little, small; young munnu\{uni;

P: minSeta

liver tira

to look, aim at noqot-

to lose ah-; bih-

loud ékkite

louse tsáamitsa

lung comba

male; bull; firestick šoqta

man; husband; male inta, $\mathrm{P}$ : yooba

many nitsina

to marry ifam-

meat cata

milk; tear eefi

to milk fir-

to miss the target $\underline{d a b b}$ -

to mix Sangat-; lax-; reekis-

molar káasala

mongoose dúbaza

monkey qaara moon; month leefa

mosquito hinano

mother ayyane

mountain kuttunko

mouth; language iifa

mud conqorte

name meša

navel gusunte; handura

neck iište; denge

needle narfi

to become night girib-

nine gollanke

nose síina

now ayki

old geccate; P: geccayke

one akkálbano

oneself ella, elella

oryx saalta

ostrich balgo

other keesa

owlet diga

ox ardo

palm lines zanitte

peace nágayko

pelican badio

pen, enclosure cayde

penis moolo

to pick up, collect boš-

to pierce, spear, sting coq-

pigeon átolla

to pinch kobis-

plain láYakko

to play iške-

play išma

to plough; to do, make danhad-

to plunge $\underline{\text { diim }}$ 
poison; medicine deeša

poor baSatuni

porcupine dangadangaco

potato tinniša

to pour, fill $\underline{\text { ucce }}$

pregnant erehte; P: erehiwa; to become pregnant erehi?-

pubic hair bositte

to pull zii?-

to pull out bul-

pumpkin gawte

pupil of the eye $\underline{\text { dunko }}$

to push tuuts

to put, store tiid-

to put down fad-; xot-

to put out goxe-

rabbit gúbale

rain haji

to raise taxay-

to reach (someone) dehad

red róomini

to rejoice xasod-

relative eeda

to rest aame-; (on the headrest) šanne-

rhinoceros oršatte

rib hinaSa

rich kamurre, SING.M kamurko, SING.F

\section{kamurte}

right mizigitte

to rise, stand up axay-

road kiti

root, vein Sizza

rope kaada

to run hay-; (P subj.) bahat-

sacrum (anat.) fulfula [pulpula]

to be sad ekkešad saliva boda

salt $\underline{\operatorname{sogo}}$

to be salty, bitter tsaqam-

sand šumaha

saucepan qaba

to say gis-

to scratch $x a a b$ -

to see yob-

seed boraho

to send away farat-

seven tahanke

to sew cig-

to have sexual intercourse šoxe-

shadow, place tágara

to shave hes-

sheep xoona

shin garaboko

short hólbatuni

shoulder kacce

to shout riir-; mees-

sibling aza

side hele

sister sodda; sister's husband úkubu; sister's son ášinkuni

six tsanafa

skin; hide darbo

to sleep tag-, tagam-

slowly; a little bit; softly íccama

to smell siinsad; (good) hagun-

to smooth (a skin with a stone) rig-

snail gode

snake gabare

to sneeze Siqqiši?-

to sniff (obj.: tampo 'tobacco') sug-

soft $\underline{\text { lattu }}$ 
son, child (male), boy maara; P: iila; son's son oofko

sorghum muusko

to speak morom-

spear tora

to spend the day was-

spider innakko

to spit bud-

star hizge

to steal geres-

sterile (F) mekente

stick toollo

to stink Sar-

stone; grinding stone caSa

to stop (intr.) dehe-

to stop, stand yaw-

strength gúlbata

stump gutula

to suck ame-; tsuub-

sun áxaco

to be surprised, shocked nah-

sweat sippa [tsippa]

to swim zoguy-

to take, get hoir -

to take, catch ta?-

tall orma

to tell Sale-

ten coma

termite $\underline{\text { irmatte }}$

testicle $\underline{\text { kirde }}$

that (faraway) áddate

there woki

thief gerela

thigh tafo

thin carba

thorn taba three zeha

throat gúmara

to thunder xaraw [haji ki...]

to be tired malal-

tobacco tampo

today burinki

tomorrow barám, barama

tongue Sádaba

tooth itima

tortoise kufe

to touch berre-

tree; wood hanca

tribe gosa

truth dugate

twins laamaxode

to twist the firesticks day

two lama

umbilical cord soorto

uncle Sabuya

urine; sperm šaaha

uvula leeleSa

vagina kano

very taSanta

village, settlement olla

to vomit SebeSe-

vulture kutsa [kutša]

to wait kab-; sal

to want haabi-

to wash hobat-

water; river caSawa

waterbuck do?osa

Weyt'o river dullaya

when? bari

(to) where? hawki; from where? hawtu

which? ayta

to whistle fidis - 
white áttomuni

who haka

why? na $=k u$

wild peas bote

wind habura

wing koola

wisdom tooth Sango

woman, wife; female ayma; P: aaka worm hangararo; zoborko

wrist sagayto

to yawn $\underline{\text { šammaYšip- }}$

year bera

yellow silbe

yesterday naxani

zebra kermayle 


\section{REFERENCES}

Amborn, Hermann, Gunter Minker, and Hans-Jürgen Sasse.1980. Das Dullay. Materialen zu einer ostkuschitischen Sprachgruppe. Berlin: Dietrich Reimer.

Bender, M. Lionel. 1994. "The Mystery Languages of Ethiopia." In Harold G. Marcus (ed.), New Trends in Ethiopian Studies. Papers from the 12th International Conference of Ethiopian Studies. Vol. 1: Humanities and Human Resources. Lawrenceville, NJ: Red Sea. Pp. 1153-74.

Bender, M. Lionel. 2000. Comparative Morphology of the Omotic Languages. München: Lincom Europa.

Blažek, Václav. 1991. "Comparative analysis of Ongota lexicon." Unpublished paper presented at the 21 st Colloquium on African Languages and Linguistics, Leiden.

Dinote Kusia (Shenkere) and Ralph Siebert. 1994. "Wordlists of Arbore (Irbore), Birayle (Ongota), Tsamai (Tsamaho)." Survey of Little-known Languages of Ethiopia Linguistic Report No. 20. Addis Ababa: Addis Ababa University, Institute of Ethiopian Studies. Pp. 1-12.

Donaldson Smith, Arthur. 1896. "Expedition Through Somaliland to Lake Rudolf." The Geographical Journal 8: 120-137, 221-239.

Federal Democratic Republic of Ethiopia. 1998. The 1994 Population and Housing Census of Ethiopia. Summary Reports at Country and Regional Levels. Addis Ababa: Office of Population and Housing Census Commission, Central Statistical Authority.

Fleming, Harold C., Aklilu Yilma, Ayyalew Mitiku, Richard Hayward, Yukio Miyawaki, Pavel Mikeš, and J. Michael Seelig.1992/93. "Ongota or Birale: A moribund language of Gemu-Gofa (Ethiopia)." Journal of Afroasiatic Languages 3, 3: 181-225.

Grimes, Barbara F. (ed). 1991. Ethnologue. Languages of the World. Eleventh Edition. Dallas: Summer Institute of Linguistics.

Grimes, Barbara F. (ed). 1996. Ethnologue. Languages of the World. Thirteenth Edition. Dallas: Summer Institute of Linguistics.

Hayward, Richard J. 1987. "Terminal vowels in Ometo nominals." In Herrmann Jungraithmayr and W. W. Müller (eds.), Proceedings of the Fourth International Hamito-Semitic Congress, Marburg, 20-22 September, 1983. Amsterdam/ Philadelphia: John Benjamins. Pp. 215-31. 
Hayward, Richard J. 1989. "Comparative notes on the language of the S'aamakko.” Journal of Afroasiatic Languages 2, 1: 1-53.

Tosco, Mauro. 2001. The Dhaasanac Language. Köln: Rüdiger Köppe.

Department of African Languages and Linguistics [Received April 2001; Leiden University P. O. Box 9515 accepted May 2001]

2300 RA Leiden, The Netherlands

g.sava@let.leidenuniv.nl

Department of African and Arab Studies

Istituto Universitario Orientale

Piazza S. Domenico Maggiore 12

I-80134 Napoli, Italy

mauro.tosco@libero.it 


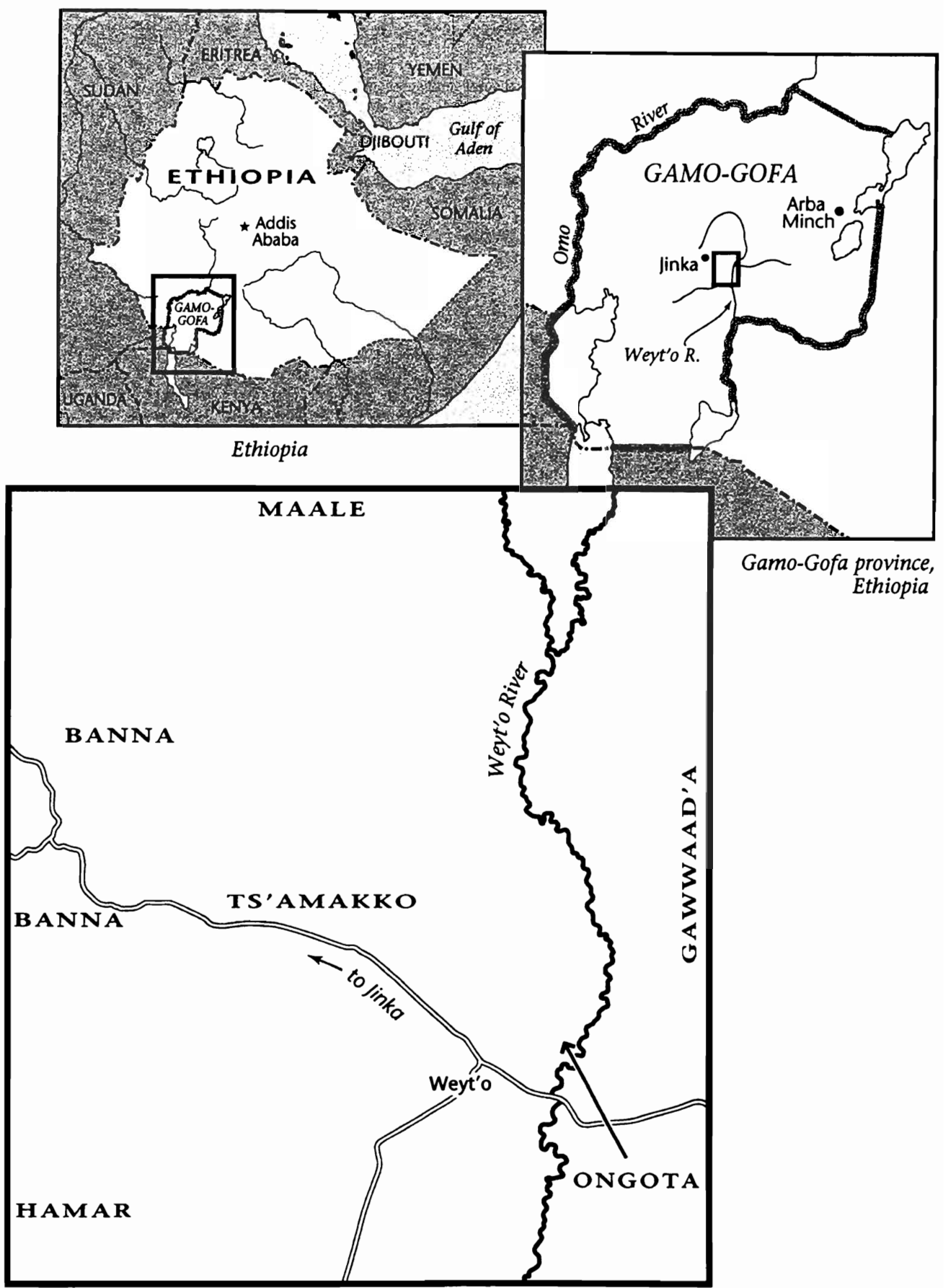

Weyt'o River area in Gamo-Gofa province, Ethiopia. 
